\title{
A NEW BOTTLE FOR RENEWED WINE: THE ARBITRATION ACT, 1991
}

\section{W.H. HURLBURT, Q.C.}

This article provides a useful overview of the 199I Arbitration Act in Alberta and its similar counterparts in Ontario and Saskatchewan including a history of legislation governing arbitrations. The author outlines the purpose and function of the Arbitration Act and discusses how the legislation has fared, so far, in the courts. The article then ends with a discussion concerning the significance of the Arbitration Act for drafiers. The appendix contains a valuable sample of case law concerning the new legislation in Alberta, Ontario and Saskatchewan.
Le présent article offre un aperçu utile de l'Arbitration Act(1991) de l'Alberta et de lois similaires adotpées en Ontario et en Saskatchewan, et inclut l'historique de la législation régissant l'arbitrage. L'auteur décrit l'objectif et la fonction de cette loi et suit la façon dont elle a été appliquée, jusqu'ici, par les tribunaux. L'article se termine par une discussion portant sur la signification de l'Arbitration Act pour les initiateurs d'ententes. L'annexe contient un exemple intéressant de jurisprudence concernant les nouvelles lois en Alberta, Ontario et Saskatchewan.

\section{TABLE OF CONTENTS}

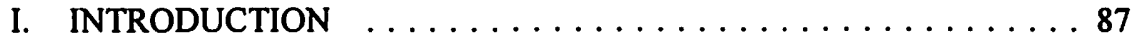

II. ARBITRATION LEGISLATION IN FORCE IN ALBERTA $\ldots . .88$

III. PURPOSE AND FUNCTION OF THE

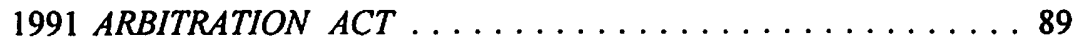

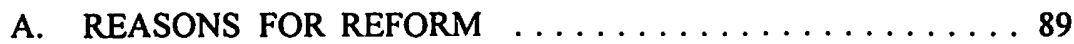

B. PRINCIPLES OF THE $1991 A C T \ldots \ldots \ldots \ldots \ldots \ldots$

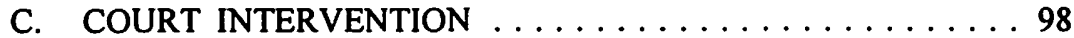

IV. JUDICIAL TREATMENT OF THE

NEW ARBITRATION ACTS $\ldots \ldots \ldots \ldots \ldots \ldots \ldots \ldots \ldots$

A. GENERAL DISCUSSION .............. 106

B. INTERPRETATION OF ARBITRATION CLAUSES . . . 110

C. RELATIONSHIP OF ARBITRATION TO MECHANICS' AND BUILDERS' LIEN LEGISLATION . . . 111

D. COURT SUPERVISION OF AWARDS $\ldots \ldots \ldots \ldots \ldots 112$

E. CONCLUSION .................... 113

V. SIGNIFICANCE OF THE $1991 A C T$

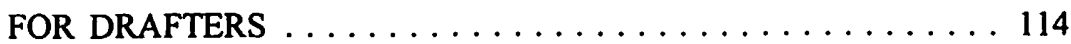

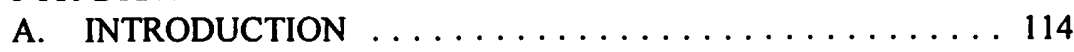

B. SCOPE OF AN ARBITRATION CLAUSE ......... 114

C. NUMBER AND QUALIFICATIONS

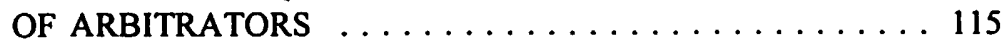

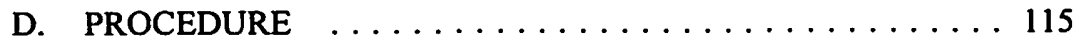

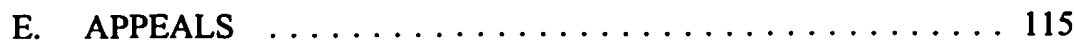

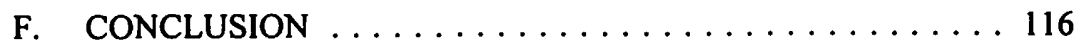

VI. GENERAL CONCLUSION $\ldots \ldots \ldots \ldots \ldots \ldots \ldots \ldots \ldots 116$

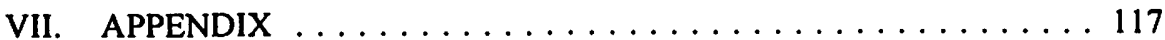

Director Emeritus, Alberta Law Reform Institute and Counsel, Reynolds Mirth Richards and Farmer. 


\section{INTRODUCTION}

Arbitration is the most litigation-like of alternative dispute resolution methods. It is essentially the adjudication of the relative rights of disputants by a neutral adjudicator who has heard the cases put forward by each. However, the disputants can tailor the process to their needs: they can avoid many of the trappings of a lawsuit; they can choose their adjudicator; and they can have their affairs kept confidential.

Arbitration affects legal rights and therefore requires a legal structure. Legislation provides that structure. Legislation governing private arbitrations in Canada has had a long history.

Until 1986, that history was uneventful. The common-law provinces and the two territories simply copied the United Kingdom Arbitration Act of 1889.' In 1931, the resulting situation commended itself to the Conference of Commissioners on Uniformity of Legislation in Canada, ${ }^{2}$ which viewed the Arbitration Acts as efficient and substantially uniform. ${ }^{3}$ However, times soon changed. By 1934, the United Kingdom itself found it necessary to amend the $1889 \mathrm{Act}^{4}{ }^{4}$ and by 1950 it became necessary to substitute a new Act. ${ }^{5}$ In 1975, that $A c t$ was amended to give effect to UNCITRAL's New York Convention On Recognition and Enforcement of Foreign Arbitral Awards of $1958,{ }^{6}$ and in 1979 further amendments were made. ${ }^{7}$ However, until 1986, the law governing private arbitrations in Canada, outside Quebec, remained cast in the comfortable uniformity of the 1889 mold.

In 1985, UNCITRAL followed up the New York Convention with its Model Law on International Commercial Arbitration. ${ }^{8}$ In March 1986, British Columbia adopted an International Commercial Arbitration Act based on the Model Law. The Uniform Law Conference of Canada then adopted a Uniform International Commercial Arbitration $A c t^{9}$ which attached the New York Convention and the Model Law as schedules and made some changes in them. The Uniform Act was then adopted by the remaining common-law provinces and the two territories. At that point, most of the provinces had one arbitration regime for international commercial arbitrations that was based on the Model Law and the New York Convention and another regime for other private nonlabour arbitrations that was based on the 1889 United Kingdom Act.

Arbitration Act, 1889 (U.K.), c. 49,52 \& 53 Vict.

Now, mercifully, known as the Uniform Law Conference of Canada.

Only Quebec and Prince Edward Island did not have the 1889 Act at that time, and Prince Edward Island subsequently enacted one: see R.S.P.E.I. 1988, c. A-16.

Arbitration Act 1934 (U.K.), 1934, c. 14.

Arbitration Act 1950 (U.K.) 1950, c. 27.

Arbitration Act 1975 (U.K.) 1975, c. 3.

Arbitration Act 1979 (U.K.), 1979, c. 42.

See "Excerpts on the Model Law: From the Report of the United Nations Commission on International Trade Law on the Work of its Eighteenth Session" (3-21 June 1985), Supplement, C. Gaz. 1986.I.5152; and also A. Gaz. 1986.I.2915.

$9 \quad 1986$ ULCC Proc. at 54-80. Uniform Law Conference of Canada, Proceedings of the Sixty-Eighth Annual Meeting (1986) at 54-80. 
When it adopted its International Commercial Arbitration Act, British Columbia broke additional new ground by adopting a new Commercial Arbitration Act to govern domestic non-labour arbitrations. ${ }^{10}$ This act modernized the arbitration process. It implemented the 1982 Report on Arbitration of the British Columbia Law Reform Commission, which was the first formal Canadian proposal for modern arbitration legislation.

At the federal level, Parliament, also in 1986, adopted the United Nations Foreign Arbitral Awards Convention Act," which enacted the substance of the New York Convention, and the Commercial Arbitration Act, ${ }^{12}$ which enacted the substance of the Model Law.

In 1988, the Alberta Law Reform Institute issued its Report 51, Proposals for a New Alberta Arbitration Act. The report included a draft Arbitration Act which started with the UNCITRAL Model Act but made significant changes to it in order to adapt it to the Alberta legal environment. At that time, the Ontario Ministry of the Attorney General was interested in developing a new Arbitration Act, and ALRI and the Ministry made a cooperative proposal for a Uniform Act to the Uniform Law Conference, which resulted in the adoption of the Uniform Arbitration Act in 1990. ${ }^{13}$

In 1991 and 1992, Alberta, Ontario, Saskatchewan and New Brunswick adopted the Uniform Arbitration Act. ${ }^{14}$ There are a few differences among the four new Acts, and one or two are of some importance, but fundamentally and in most of the details, the four are the same.

\section{ARBITRATION LEGISLATION IN FORCE IN ALBERTA}

The 1991 Arbitration Act applies to all non-labour arbitrations governed by Alberta law ${ }^{15}$ unless it is specifically excluded by agreement or statute. ${ }^{16}$ The Act itself excludes from its scope arbitrations that fall under Part 2 of the International Commercial Arbitration $\mathrm{Act}^{17}$ and arbitrations under a number of statutes that have arbitration provisions for labour relations. ${ }^{18}$

S.B.C. 1986 , c. 3 .

S.C. 1986 , c. 21.

S.C. 1986 , c. 22.

1990 ULCC Proc. at 36, 86-122. Uniform Law Conference of Canada, Proceedings of the SeventySecond Annual Meeting (1990) at 36, 86-122.

Arbitration Act, S.A. 1991, c. A-43.1; Arbitration Act, S.0. 1991, c. 17; Arbitration Act, S.S. 1992, c. A-24.1; Arbitration Act, S.N.B. 1992, c. A-10.1.

The question of when Alberta arbitration law applies is an important question but is beyond the scope of this paper.

Alberta Arbitration Act, supra note 14, s. 2(1).

Ibid., s. 2(1)(b), referring to the International Commercial Arbitration Act, R.S.A. 1980, c. 1-6.6 [hereinafter the "ICAA"].

Arbitration Act, ibid., s. 2(3). The statutes listed are: Banff Centre Act; Cancer Programs Act; Colleges Act; Labour Relations Code; Police Officers Collective Bargaining Act; Public Service Employee Relations Act; Technical Institutes Act; and Universities Act. Section 2(4) allows other acts to be excluded by regulation. No such regulation has been made. 
So, apart from the Arbitration Act, the following arbitration regimes apply in Alberta:

\section{The International Commercial Arbitration Act}

Subject to a few special provisions, the ICAA applies the UNCITRAL Model Law (Schedule 2) to "international commercial arbitration"19 in Alberta. ${ }^{20}$ Despite basic similarities, the 1991 Arbitration Act is different from the Model Law as enacted by the ICAA. It is therefore important to determine whether the Arbitration Act or the ICAA applies to a specific case. If the parties, the place of performance of the principal agreement or the place of the arbitration have any non-Alberta flavour, or if the parties agree that the ICAA is to apply, the reader should consult article 1 of the Model Law, as its description of what is "international" is complex and may bring the case under the ICAA. An additional consideration is that the arbitration must be "commercial" as well as international in order to come under the ICAA, and it may not always be easy to decide whether the specific case falls within that category. ${ }^{21}$

\section{Federal Arbitration Act}

An arbitration under federal law is subject to the Commercial Arbitration Act (Canada) $^{22}$ rather than the Arbitration Act (Alberta). While the federal Act is also based on the Model Law, it is significantly different from the 1991 Alberta Act.

\section{Labour-relations arbitration regimes}

Labour-relations arbitrations perform very different functions from ordinary private arbitrations and are based on different premises. It is highly unsafe to apply the law and practice under the Arbitration Act to the labour-relations arbitrations that are excluded from it.

\section{PURPOSE AND FUNCTION OF THE 1991 ARBITRATION ACT}

\section{A. REASONS FOR REFORM}

The old Arbitration $\mathrm{Act}^{23}$ left many questions unanswered and many practical problems unresolved. That was one reason for calls to modernize it. A second reason was that the relationship between arbitration and the courts reflected in the old Act was no longer seen as appropriate.

What relationship between arbitration and the courts is appropriate?

ICAA Schedule 2, art. 1.

The ICAA also applies the New York Convention to the enforcement of foreign arbitral awards in Alberta, but that is not relevant to this discussion.

In Borowski v. Heinrich Fiedler Perforiertechnik GmbH (1994), 22 Alta L.R. (3d) 366, [1994] 10 W.W.R. 623, 158 A.R. 213 (Q.B.), Justice Murray held that a contract of employment is not commercial although the activities for which the employee is employed are commercial.

S.C. 1986, c. 22.

Arbitration Act, R.S.A. 1980, c. A-43 and its predecessors. 
Arbitration is adjudication. Disputing parties have agreed to have their dispute adjudicated by a private arbitrator rather than by a court. Having made an agreement, they should be able to hold each other to it. Court intervention in an arbitration derogates from that agreement.

But some court intervention is essential, or at least highly desirable. Courts must establish the jurisdictional boundaries of arbitrators. Courts must protect arbitrations against pre-emption by court proceedings. Courts should have the power to fill lacunae in arbitration agreements, such as the lack of adequate provision for the appointment of arbitrators. Courts should have the power to assist arbitrations by interim injunctions, by preservation orders and by assisting in obtaining evidence. Courts should provide recourse against an unfair, biased or dishonest arbitration. Some recourse against arbitrators' errors in law may also be desirable. The machinery for the enforcement of court judgments should be made available for the enforcement of arbitrators' awards.

There is tension between the notion of arbitration as a process that the parties have chosen to the exclusion of court processes, on the one hand, and the need for or desirability of court supervision and assistance, on the other. The Acts based on the Arbitration Act 1889 (U.K.) struck one balance between them. The Arbitration Act 1991 and its counterparts have struck a different balance.

The old Acts gave the courts a great deal of discretionary supervisory powers. For example,

- a court could allow a dispute to be litigated despite an arbitration agreement if there was a "good reason" for not proceeding with the arbitration;

- a court could remove an arbitrator or quash an award if the arbitrator "misconducted himself," words which came to be interpreted to include committing almost any error of procedure or law;

- a court could permit the revocation of a submission to arbitration;

- a court, in its discretion, could decline to enforce an arbitrator's award;

- a court could order an arbitrator to "state in the form of a special case any question of law arising in the course of the reference."

The new Arbitration Act, although it continues to give the Court of Queen's Bench substantial powers to assist and correct the arbitration process, structures those powers and reduces the discretionary elements in them.

\section{B. PRINCIPLES OF THE $1991 A C T$}

The $1991 \mathrm{Act}$ is based on the following principles:

a) Party autonomy and control.

The Act promotes party autonomy and control by giving the parties power to vary or exclude anything in the Act with specific exceptions (or even to opt out of the 
whole $A c t$ ). The consequence is that the parties to an arbitration can determine how the arbitration is to be conducted.

b) Efficiency.

The Act promotes efficiency:

- $\quad$ by providing a structure and process for arbitrations;

- $\quad$ by providing for court assistance where necessary;

- $\quad$ by permitting the parties to vary the statutory structure and process to meet their specific needs;

- by requiring parties who have objections to the process to bring them forward in a timely way;

- by conferring ancillary powers on arbitral tribunals that they may or may not have had under the old Acts;

- by restricting court intervention in the arbitration to cases in which it is needed for efficiency or to ensure faimess and equal treatment or basic legality; and

- by requiring the Court of Queen's Bench to enforce arbitrators' awards.

c) Fairness and equal treatment.

The Act promotes fairness and equal treatment by imposing on arbitrators a duty to provide it and by providing for court intervention to ensure that arbitrators carry out that duty.

Those principles will now be discussed in greater detail.

\section{Party Autonomy and Control}

An arbitration occurs because the parties to it have agreed to have a dispute decided by an arbitrator or arbitrators rather than by a court. By agreeing to arbitration the parties have expressly, or, more often, by implication, agreed to participate in the arbitration and to honour the arbitrator's award. The foundation of an arbitration is a contract, and for that reason, arbitration is based upon contract law.

The underlying agreement to arbitrate is governed entirely by the law of contract. The Arbitration Act does not say anything about it.... The courts will interpret it on the same principles as they interpret other legally binding contracts and will apply all the rules of contract law to it. ${ }^{24}$

The basic consensual nature of arbitration must not be overlooked. Disputing parties choose to have their dispute decided by arbitration. Their agreement establishes the arbitration. They should be able to control the arbitration. The 1991 Act gives effect to this principle. 
First, parties can opt out of the Act entirely. Section 2(1) says, in effect, that the Act will not apply if it "is excluded by an agreement of the parties or by law." Opting out, without more, would leave the arbitration to the common law, the content of which would be difficult to determine after a century of arbitration legislation, so that it is likely to prove unwise to opt out of the Act without opting into some other arbitration regime. However, the right to opt out is there.

Second, s. 3 says that the parties "may agree, expressly or by implication, to vary or exclude any provision of this Act," with 7 listed exceptions. These exceptions put beyond parties' control:

a) the requirement that the parties be treated fairly and equally;

b) the supervisory powers of the Court of Queen's Bench, which are designed to ensure legality, fairness and equal treatment; and

c) the power of the Court of Queen's Bench to enforce an award. ${ }^{25}$

These exceptions are important, but for all practical purposes they leave the parties free to tailor the arbitration to suit their needs.

There is another side to the party autonomy coin. An arbitration can be forced only on a party who has agreed to it in accordance with the usual principles of contract. ${ }^{26}$ So s. 45 gives the Court of Queen's Bench the power to set aside an award if there is a fundamental legal flaw in the agreement or in the establishment of the arbitration ${ }^{27}$ and s. 47 provides that a party who has not participated in an arbitration can get an advance declaration that the arbitration is invalid on similar grounds. The parties cannot vary or exclude these Court of Queen's Bench powers, though, under other parts of s. 45 , failure to raise a timely complaint about some of these matters will effectively waive the right to raise them later.

\section{Fairness and Equal Treatment}

No one, the 1991 Act assumes, would agree to an adjudication that is unfair or biased - or at least one that is biased or unfair as against oneself. So s. 19 requires an arbitral tribunal to treat the parties equally and fairly and to allow them to present a case and to respond to the other parties' cases, and s. 19 cannot be varied or excluded. Then, to ensure that arbitral tribunals do give fair and equal treatment, s. 45(1)(c) gives the Court of Queen's Bench the power to set aside an award on the grounds of unfair

There are also two minor exceptions, s. 5(2) (Scott v. Avery clauses) and s. 39 (power of the Court of Queen's Bench to extend the time for the delivery of an award).

There is an exception. A statute can legislate for an arbitration.

E.g., legal incapacity of a party to the arbitration agreement; invalidity or termination of the arbitration agreement; inclusion in an award of something not covered by the arbitration agreement; composition of the arbitral tribunal at variance with the arbitration agreement or with the Act, or the subject-matter of the arbitration is not capable of being the subject of arbitration under Alberta law. 
process, ${ }^{28}$ procedure that did not comply with the arbitration agreement or the $A c t$, corruption or fraud on the part of the arbitrator, and fraud in the obtaining of the award. The requirement of arbitrators' independence and impartiality under s. 11 and requirements of notice and disclosure of information under s. 26 are also fairness provisions.

\section{Efficiency}

a. Arbitration process and structure

\section{i. General discussion}

The old Arbitration Act gave little guidance to arbitrators, parties and counsel about procedure. The 1991 Act is intended to provide a relatively complete procedural framework which, with a valid arbitration agreement and nothing more, will enable arbitrators, parties and counsel to conduct an arbitration. That is to say, an arbitration agreement could simply provide that disputes answering to a certain description shall be submitted to arbitration, and the Act would do the rest.

That is not to say that anyone should enter into such an arbitration agreement. Default provisions in the Act cannot be satisfactory for all arbitrations, as arbitrations may cover anything from a dispute over a defective toaster to a dispute over the loss caused by a defective bridge and to the division of matrimonial property. For example, the Act's default provision for the appointment of an arbitrator by the Court of Queen's Bench is a necessary backstop, but it involves a court application which should be made unnecessary by a more efficient provision; and an arbitration agreement may prove unsuitable if it does not provide for bringing into the arbitration and binding all parties who are necessary for the disposition of all disputes arising out of one fact situation. The drafter of an arbitration agreement either should be satisfied that the Act provides for a matter in a way that is suitable for the arbitrations that may arise under the agreement, or if not so satisfied, should put into the arbitration agreement something that will be suitable.

\section{ii. Commencement of arbitration}

Sections 23 and 24 make efficient provision for the commencement of an arbitration. An arbitration may be commenced "in any way recognized by law," including the service of a notice of one of a number of kinds. If the arbitration is commenced without identifying the matters in dispute, all matters in dispute under the agreement are referred to arbitration. 
[VOL. XXXIV, NO. 1 1995]

\section{iii. Arbitral tribunal}

Sections 9 to 16 are grouped under the heading "Arbitral Tribunal." They provide machinery for constituting and reconstituting an arbitral tribunal. They contain the following provisions:

1) In default of agreement there will be one arbitrator who will be appointed by the Court of Queen's Bench, which also has a default power to appoint a substitute arbitrator in case of need. ${ }^{29}$

2) Section 11 provides that an arbitrator-and this includes a party-appointed arbitrator-shall be independent of the parties and impartial as between them, and imposes a consequential duty of disclosure on arbitrators.

3) Section 13 requires challenges to an arbitrator to be made to the arbitral tribunal and then to the Court of Queen's Bench, which has the power under s. 15 to remove an arbitrator for inability to act, corruption, fraud, undue delay or failure to treat the parties fairly and equally. ${ }^{30}$

\section{iv. Jurisdiction of arbitral tribunal}

The Act provides a framework for the consideration of jurisdictional questions under the heading "Jurisdiction of Arbitral Tribunal." Section 17(1) gives an arbitral tribunal power to rule on its own jurisdiction, including objections as to the existence or validity of the arbitration agreement (which is to be treated as an independent agreement that may survive a principal agreement within which it is contained). Section $17(2)$ gives an arbitral tribunal power to determine questions of law that arise during the arbitration. Both of these powers are subject to recourse to the Court of Queen's Bench, which has the ultimate control over jurisdictional boundary questions.

In the interests of efficiency, s. 18 confers on a tribunal incidental powers to order the detention, preservation or inspection of property and documents that are the subject of the arbitration and to order security, and it confers the power on the Court of Queen's Bench to enforce such orders.

\section{v. Conduct of arbitration}

Sections 19 to 30 are gathered under the heading "Conduct of Arbitration" and are intended to provide an efficient framework for that process.

Subject to the overriding duties of fairness and equal treatment under s. 19, the fasciculus provides an efficient structure for the arbitration: appointment of a substitute under $s$. 16. No substitute can be appointed if the agreement provides that the arbitration is to be conducted only by a named arbitrator. 
- Section 20(1) confers on the arbitral tribunal power to determine the procedure to be followed, and s. 22 confers on the tribunal supplementary powers to determine times, dates and places.

- Section 26(1) gives the tribunal the power to conduct an arbitration on the basis of documents unless a hearing is demanded, in which event there must be a hearing.

- Section 25 gives the tribunal the power to require the parties to submit "statements," which amount to pleadings, and s. 27 gives it the power to dismiss the claim of a claimant who does not submit a timely statement or to proceed without a statement in the case of another party.

- Section 27(4) gives the tribunal the power to terminate an arbitration for unreasonable delay by the party who commenced the arbitration, or to give directions for speedy determination.

- Section 25(6) gives the tribunal a general power to give directions with which the parties must comply, including directions to the parties to submit to examination on oath or affirmation and to produce records and documents. ${ }^{31}$

- Section 21 provides that the tribunal is not bound by the rules of evidence and has the power to determine admissibility, relevance and weight, and the manner in which evidence is to be admitted. ${ }^{32}$

Under s. 29(1) and s. 29(2), a person served with a notice to attend to give evidence and produce records must do so, subject to privileges, and under s. 29(5) the Court of Queen's Bench may make orders and give directions with respect to the taking of evidence as if the arbitration were a court proceeding.

\section{vi. "Award and Termination of Arbitration"}

Some important provisions appear in ss. 31 to 43 under the heading "Award and Termination of Arbitration":

- Section 31 requires an arbitral tribunal to decide a dispute in accordance with law, and s. 33 requires it to decide in accordance with the arbitration agreement and the principal contract and to take applicable usages of trade into consideration.

- Section 31 gives a tribunal the power to order equitable remedies.

31 The Court of Queen's Bench has power to enforce any such direction as if it were a direction made by it in an action: s. 25(7).

32 However, under s. 29(4), the tribunal must require witnesses to testify under oath, affirmation or declaration. 
- Section 38 provides that an award must observe specified formalities, one of which is the giving of reasons; and, under s. 40 the tribunal can be requested by a party and required by the Court of Queen's Bench to give a further explanation.

- Section 41 gives a tribunal the power to make interim awards and more than one final award.

- Section 43 gives a tribunal the power to:

- correct typographical, calculation and similar errors in an award;

- correct an injustice caused by tribunal oversight; and

- make an additional award to deal with a matter that was omitted from the earlier award.

The tribunal must exercise its corrective powers under section 43 within rigid thirty day time lines, though the starting point of the thirty days varies.

\section{b. Timely objection}

Included in the efficiency principle of the $1991 \mathrm{Act}$ is a minor principle, that a party who has an objection to an arbitration or to anything done in the course of an arbitration must raise it in a timely manner. ${ }^{33}$ Parties may not wait to see how the arbitration wind is blowing or has blown before taking an objection. The following provisions give effect to that principle:

- Section 4 provides that a party waives a right to object to a non-compliance with the Act or with the agreement unless they raise it within a limited time provided for it or within a reasonable time. Since the parties cannot exclude or vary any of the provisions entrenched by s. 3 , the waiver principle does not apply to any rights conferred by those provisions.

- Section 13(2) provides that a party who appointed an arbitrator or participated in an appointment may challenge the arbitrator only on grounds of which the party was unaware at the time of the appointment.

- Section 13(3) provides that a party must send the tribunal a statement of the grounds for the a challenge to an arbitrator within fifteen days of becoming aware of them, and must apply to the court within ten days if the tribunal rejects the challenge.

- Section $17(4)$ provides that a party who objects to jurisdiction must do so no later than the beginning of the hearing or, if there is no hearing, no later than the first occasion on which the party submits to the tribunal a statement under s. 25. 
- Section 17(6) provides that a party who objects to the tribunal exceeding its jurisdiction must do so as soon as the matter alleged to be beyond the tribunal's jurisdiction is raised during the arbitration, and must apply to the court within thirty days of an adverse ruling by the tribunal.

- Sections 45(4) to 45(6) prohibit the Court of Queen's Bench from setting aside an award on grounds that should have been raised earlier under the provisions listed above. ${ }^{34}$ Section $45(3)$ adds to the list of prohibitions the case in which a party has waived the right to object to the inclusion of a dispute in the arbitration or in the award or has agreed to the inclusion. ${ }^{35}$

\section{c. No-appeal provisions}

Appeals from the Court of Queen's Bench to the Court of Appeal on procedural matters will delay an arbitration and add to its cost. They may be used as a means of obstruction and delay. The $1991 \mathrm{Act}$ therefore prohibits appeals in a number of situations in which the question is merely one of choice of forum, that is, a choice between court and arbitrator or between arbitrators. The Court of Queen's Bench orders that cannot be appealed are as follows:

- the grant or refusal of a stay of a competing court action under s. 7;

- the appointment or refusal to appoint an arbitrator under s. 10 or a substitute arbitrator under s. 16;

- an order under s. 15(1) removing or refusing to remove an arbitrator and an order under s. 15(3) giving directions on the conduct of the arbitration when an arbitrator is removed; ${ }^{36}$

- an order under s. 17(9) disposing of an objection to jurisdiction.

Section 8(3), on the other hand, provides for an appeal, with leave of the Court of Appeal, from the Court of Queen's Bench's determination of a question of law. However, under s. 8(2), the question of law will not get to the Court of Queen's Bench in the first place without the consent of either the arbitral tribunal or all parties. This is a safeguard that differentiates the question-of-law provision from the stated case that could be ordered by the court under the old Arbitration Act on the application of a

One exception is that the court may set aside an award if satisfied that a failure to raise an objection to jurisdiction was justified. Note also that, under s. 47, a party who has not participated in an arbitration is entitled at any stage to a declaration that an arbitration agreement does not apply to a dispute.

The waiver provisions do not apply to the court's power to set aside an award on the grounds that a party to the arbitration agreement was under a legal incapacity or on the grounds that the arbitration agreement is invalid or has ceased to exist. In such a case, the party attacking the award would no doubt say that expressio unius est exclusio alterius so that waiver does not apply. A party supporting an award may argue estoppel. subsection, the Court of Queen's Bench, if it removes an arbitrator for corruption, fraud or undue delay, may deny compensation to the arbitrator and require the arbitrator to pay costs. 
single party. It is hoped that the new provision will make the court's assistance available where it is needed without providing an opportunity for obstruction and delay.

The no-appeal provisions make individual judges of the Court of Queen's Bench the final arbiters in choice-of-forum matters. The hope is that, without imposing injustice on the parties, this device will avoid the use of appeals that would obstruct and delay arbitrations.

\section{COURT INTERVENTION}

\section{General Discussion}

The 1991 Act gives extensive powers to the Court of Queen's Bench. ${ }^{37}$ A number of these powers enable the court to facilitate arbitrations. These are based on the principle of efficiency. Others enable the court to supervise arbitrations. These give effect to the principles of party autonomy and fairness.

Section 6 makes the intention of the Act clear. It reads as follows:

6. No court may intervene in matters governed by this Act, except for the following purposes as provided by this Act:

(a) to assist the arbitration process;

(b) to ensure that an arbitration is carried on in accordance with the arbitration agreement;

(c) to prevent manifestly unfair or unequal treatment of a party to an arbitration agreement;

(d) to enforce awards.

This section tells the courts very clearly that their powers are to be used only to give effect to the principles of party autonomy, fairness and efficiency. It should be the starting point of every judicial action under the $A c t$.

\section{Court Powers of Assistance}

The efficient conduct of an arbitration often requires the exercise of powers that a party or an arbitral tribunal does not have. Under the efficiency principle, the $1991 \mathrm{Act}$ therefore gives the Court of Queen's Bench ${ }^{38}$ substantial powers to assist the arbitration process. References have already been made to several of them, but they will be listed together here for overview purposes: to stay an action in Provincial Court where the subject matter is subject to an arbitration agreement. Otherwise, the Act gives powers only to the Court of Queen's Bench. 
- Section 7(1) gives the Court of Queen's Bench and the Provincial Court power (and imposes a duty) to stay a court action brought in respect of a matter that is to be submitted to arbitration under an arbitration agreement. Section 7(2) limits the court's power to refuse a stay to a specific list of cases. If the court refuses a stay, the matter in dispute cannot be arbitrated.

- Section 8(1) gives the Court of Queen's Bench the same powers with respect to the detention, preservation and inspection of property, interim injunctions and the appointment of receivers as it has in court actions.

- Section 8(2) gives the Court of Queen's Bench the power to determine any question of law that arises during an arbitration, but only with the consent of all parties or of the arbitral tribunal.

- Section 8(4) gives the Court of Queen's Bench the power to consolidate arbitrations, but only on the application of all parties.

- Section 10(1) and s. 16(2) give the Court of Queen's Bench default powers to appoint an arbitrator.

- Section 25(7) gives the Court of Queen's Bench the power to enforce a direction of an arbitral tribunal with respect to an arbitration, including a direction to a party to submit to examination or produce records and documents.

- Section 29(5) gives the Court of Queen's Bench the power to make orders and give directions with respect to the taking of evidence for an arbitration as if the arbitration were a court proceeding.

- Section 39 gives the Court of Queen's Bench the power to extend the time within which an arbitral tribunal is required to make an award.

- Section 49 requires the Court of Queen's Bench to give a judgment enforcing an Alberta award if the time for appeal or setting aside has expired without proceedings being taken to have the award set aside or declared invalid. ${ }^{39}$ The court has the same powers with respect to the enforcement of arbitral awards as it has with respect to the enforcement of its own judgments. appeal, an application to set aside or an application for a declaration of invalidity is pending. Section 49 also extends to awards made in Canada outside Alberta, with a slightly longer list of exceptions. 
3. Court Supervision

a. Court supervision during an arbitration

While an arbitration is in process, the Court of Queen's Bench has two supervisory powers:

1) the power under s. 13(6) and s. 15(1) to remove an arbitrator for bias, lack of agreed qualification, corruption, fraud, undue delay or failure to give the fair and equal treatment or the opportunity to present and rebut cases that are mandated by $s .19$.

2) the power under s. 17(9) to rule on an objection to an arbitral tribunal's jurisdiction.

The Court of Queen's Bench's power to rule on an objection to jurisdiction gives effect to the principle of party autonomy -an arbitration must stay within the agreed boundaries-and so does the power of removal of an arbitrator for lack of agreed qualification. Removal on the grounds of undue delay is primarily based on the efficiency principle. Removal on the other grounds listed above is based on the principle of fairness and equal treatment.

\section{b. Court supervision of awards}

\section{i. Setting aside}

Under the old Arbitration Act, an award could be set aside on the grounds that the arbitrator had "misconducted himself." Under judicial interpretation,

the word "misconduct" is given a very wide meaning going beyond any sense of moral culpability and including an error in law on the face of the award. That which would be mere regrettable error, if done by a judge, earns for the arbitrator the opprobrium of "misconduct" with whatever double standard that may involve. ${ }^{40}$

Thus, the old Act conferred a broad discretionary power to set aside an award on grounds that included procedural error and bias, as well as morally culpable conduct such as fraud.

The 1991 Act substitutes for the former broad discretion an itemized list of grounds for setting aside an award. Of the nine paragraphs of s. 45(1), five $e^{41}$ have to do with specific fundamental flaws in the arbitration agreement or in the establishment of the arbitration which would make the enforcement of an award an invasion of party arbitration agreement); (c) (inclusion of dispute not covered by the arbitration agreement); (d) (composition of the tribunal was not in accordance with the arbitration agreement or the $A c t$ ); and (e) (the subject matter of the award is not capable of arbitration under Alberta law). 
autonomy, and three $e^{42}$ have to do with departures from faimess and equal treatment. Section $45(1)(g)$ (failure of procedures to comply with the Act or the arbitration agreement) has to do with either or both of party autonomy and fairness and equal treatment. Upon setting aside an award, the Court of Queen's Bench may remit the award to the arbitral tribunal with directions, or may remove an arbitrator or the tribunal and give directions for the future conduct of the arbitration. ${ }^{43}$

These are extensive powers. They are, however, directed with some precision to specific evils. There are also some restrictions on their exercise. Under s. 45(1)(f), the power to set aside arises only if the applicant was treated manifestly unfairly or unequally; whatever this means, it suggests that there is a fairly heavy onus on the applicant to show that they have suffered from unfairness or inequality of treatment. Then ss. 45(3) to 45(6) say that awards are not to be set aside on a number of grounds if timely objection was not taken; this restriction does not prevent an award being set aside for a fundamental flaw in the arbitration agreement or for a fundamental failure of fair and equal treatment.

In summary, the Court of Queen's Bench can set aside an award if there is a fundamental flaw in the arbitration agreement or the arbitration, or if there was a serious flaw or strong element of unfairness or illegality in the arbitration. But, if the complaint has to do with the conduct of the arbitration, it must be raised in a timely way unless it goes to a basic lack of fairness and equal treatment.

\section{ii. Appeals to the Court of Queen's Bench}

Section 44 of the Act makes two separate provisions for appeals to the Court of Queen's Bench from arbitration awards:

1) Under s. 44(1), a party may appeal on any issue ${ }^{44}$ "if the arbitration agreement so provides."

2) Under s. 44(2), a party may appeal on a question of law, but only with leave of the Court of Queen's Bench, and the leave is not to be granted unless the court is satisfied that the importance of the question to the parties justifies an appeal and that the determination of the question will significantly affect the parties' rights. a case, or lack of proper notice of arbitration or appointment of arbitrator); (h) (corruption, fraud or bias on the part of an arbitrator); (i) (obtaining of the award by fraud).

43 Section 45(7),(8).

4 The wording of s. 44(1) is actually "on a question of law, on a question of fact or on a question of mixed law and fact." 
Section 44(2) is one of the provisions which, under s. 3, cannot be varied or excluded. The guarantee of an appeal on law appears to be an expression of the principle of fairness and equality: an arbitration must give a party its legal rights. ${ }^{45}$

The parties thus have two alternatives to choose from. One is to agree on a right of appeal, which is under their control and which they may frame as broadly or as narrowly as they wish, with or without safeguards. The other is the statutory appeal for which leave is required and which is restricted to an appeal on a question of law. The subject is one that a drafter of an arbitration clause or agreement might usefully consider in light of the kinds of disputes that may arise and what it is that the parties want out of arbitration.

The parties to an arbitration agreement could, if they wish, exclude s. 31, which requires an arbitral tribunal to decide a matter in dispute in accordance with law. While such an exclusion would not necessarily preclude an appeal on a question of law, it would make it more difficult to find an appealable question of law.

It seems likely that the standard of review of an appeal on a question of law will be the "correctness" or "judicial standard"; that is, the court will allow the appeal unless the arbitral tribunal got its law right. A passage in Willick v. Willick ${ }^{46}$ suggests that, where the arbitration agreement provides for an appeal on fact or on mixed fact and law, the same standard of review will apply. In the past, the courts have not substituted their own view of the facts for arbitrators' views, and it would be prudent to wait for further judicial interpretation before accepting that proposition. ${ }^{47}$

\section{iii. Questions of law expressly referred}

Section 44(3) makes an exception to both s. 44(1) and s. 44(2): it says that there is no appeal "on a question of law which the parties expressly referred to the arbitral tribunal for decision." Section 44(3) was a late addition to the 1991 Act and is not included in the 1991 and 1992 Acts of the three other provinces. It was intended to provide a narrow exclusion similar to that which the courts had developed under the old Acts.

Two Court of Queen's Bench decisions suggest a broader construction of s. 44(3), that is, that a question of law which arises in the course of deciding a referred dispute 45(1) provides for an appeal on law "if the arbitration agreement does not deal with appeals on questions of law." Under the Ontario provision, the parties can agree that there is to be no appeal on law; under the Alberta provision they cannot. (1994), 158 A.R. 52 (Q.B.).

47 For a discussion of standards of review of awards agreeing with the application of the "judicial" or "correctness" standard to an arbitrator's findings of law and disagreeing with the application of the standard to arbitrator's findings of fact, see Hurlburt, infra note 48 at 181-85. 
is "expressly referred" even though the question is not mentioned in the reference. ${ }^{48}$ Until the interpretation of the words is clarified, drafters should be particularly careful to say what questions of law are "expressly referred," so as to be sure of getting the benefit of the exclusion, if that is what they want, or of getting the benefit of an appeal on law, if that is what they want.

A third Court of Queen's Bench decision, Aztec Construction Ltd. v. Frocan Industrial Contractors Ltd. et al. ${ }^{49}$ has taken s. 44(3) farther in another direction. In that case, one of the questions referred to the arbitrator was: "Did Frocan make a unilateral mistake which would void the subcontract?" The arbitrator held that:

Frocan made a unilateral mistake as to motive, but not as to the term of the Contract. Aztec's failure to identify a mistake which should have been plainly evident, is cause to void the Contract." ${ }^{\text {s0 }}$

On appeal to the Court of Queen's Bench, Aztec argued that this decision was based on a principle other than that of unilateral mistake. The Court of Queen's Bench held that what Aztec was disputing on the appeal was the arbitrator's interpretation of the law of unilateral mistake and went on to say that

it is clear that by s. 44(3) of the Arbitration Act a party may not appeal an award to the court on a question of law which the parties expressly referred to the arbitral tribunal for decision. ${ }^{51}$

The referred question includes two questions: (1) What mistake, if any, did Frocan make? and (2) If Frocan made a mistake, was that mistake a unilateral mistake that would void the contract? The first question is one of fact. The second is probably one of law. The result of the decision is thus that s. 44(3) precludes an appeal on a question of law is expressly referred for decision, even though the question referred also includes a question of fact.

Aztec also appealed the arbitrator's award of solicitor and client costs to Frocan. According to the judgment,

The parties explicitly agreed to grant to the arbitrator "complete discretion with respect to the award of costs including ... [f]ees and expenses of counsels for the disputants." 52

Pachanga Energy Inc. v. Mobil Investments Canada Inc. (1993), 8 Alta. L.R. (3d) 284 (Q.B.); affirmed without dealing with this point (1994), 15 Alta. L.R. (3d) 1 (C.A.); and Willick v. Willick (1994), 158 A.R. 52 (Q.B.). In Willick, for example, the court held that a referral of "spousal support" and "such other issues that arise out of the above" constituted an express referral of the duration of the support and thus precluded an appeal from the legal basis on which the arbitrator had determined the duration of the support. For a statement of reasons for disagreeing with these applications of s. 44(3), see W.H. Hurlburt, "Case Comment: Willick v. Willick: Appeals from Awards under the Arbitration Act" (1994) 33 Alta L. Rev. 178 at 185-88.

(1994), 161 A.R. 314 (Q.B.).

Ibid. at 317.

Ibid. at 320.

Ibid. 
The court said "[a]s the arbitrator's Award of Costs was completely within his jurisdiction, that matter cannot be appealed on the basis of the arbitrator committing an error in principle ${ }^{453}$ and cited the Pachanga case. While the court did not refer specifically to s. $44(3)$ on this point, the reference to Pachanga suggests that the decision was based on the subsection. Further, an award that commits an error in principle is appealable under s. 44(1) and s. 44(2), so that s. 44(3) must be the basis of the decision. Here again, the effect of s. 44(3), as interpreted, is to preclude an appeal on a question that includes the facts as well as the law on which a costs award is based.

So a "question of law" may include a question that has elements of fact in it and a "question of law expressly referred" may include a question that is not mentioned in the reference. Section 44(3) was intended to protect awards against appeal in very restricted circumstances, but it seems to be developing a life of its own and to be trenching on the rights of appeal under s. 44(1) and s. 44(2).

\section{iv. Declarations of invalidity of arbitration}

Section 47 permits a party to apply at any stage during or after an arbitration for a declaration that the arbitration is invalid because of one of a specified list of fundamental flaws. These flaws are: that a party to the arbitration agreement was under a legal incapacity; that the arbitration agreement is invalid or has ceased to exist; that the subject-matter is not capable of arbitration under Alberta law; and that the arbitration does not apply to the matter in dispute. However, the application may be made only if the applicant has not participated in the arbitration.

Section 47 is in part based on faimess: if the arbitration process is non-existent, an alleged party should not have to wait until arbitrators are appointed without lawful authority and then go to those arbitrators for a decision on the point. But it also recognizes that, in the event of disagreement, it is for the courts to deal with matters of fundamental or boundary jurisdiction. If $\mathrm{s} . \mathbf{4 7}$ did not exist, a court would probably entertain an application under its inherent jurisdiction for a declaration that an arbitration which threatens a person's interests is legally non-existent or invalid, so that s. 47 may do little more than declare the law that would exist without it.

\section{v. Other judicial review powers}

In Willick, ${ }^{54}$ the court said that s. 44(3) (which precludes an appeal on a question of law expressly referred to the arbitrator) does not completely oust the court: the court can still interfere if there is a "gross error of law apparent on the face of the record," the applicable standard of review being the "patently unreasonable" standard. In my submission, there is no such power. 
Even under the old $A c t$ there was no such power. As Justice Laycraft said in Mijon Holdings: ${ }^{55}$

The result of Snider v. Miller, followed in Alberta for more than $\mathbf{5 0}$ years, is that "unless a contrary intention is expressed therein" any submission to arbitration becomes an order of the court and thereby comes under the ambit of the statute. In my view whether or not it becomes an order of the court, a submission is governed by the statute.... In my view the legislature in the Arbitration Act has set forth provisions applicable to all arbitrations. It is therefore not open to a party to an arbitration to contend that he is proceeding under the common law jurisdiction rather than under the Arbitration Act. Each submission comes under the Act so that all subsequent proceedings relate to that statutory jurisdiction.

And later:

In my view, Snider v. Miller, establishes that the Alberta legislature did attempt "to define comprehensively the scope of the jurisdiction to set aside awards." ${ }^{\text {"6 }}$

What of the new Act? Section 6 says that the court is not to intervene except for specified purposes which are not relevant to this discussion, and except "as provided by this Act." But the Act does not go on to provide for judicial review. Indeed, s. 37 says that an award "binds the parties unless it is set aside or varied under ss. 44 or $45^{\prime \prime}$ and is therefore adverse to any inherent power in the court to set aside an award. Sections $37,44,45$ and 47 , in my submission, constitute a complete statutory scheme which excludes any residual court powers more emphatically than did the old $A c t .^{57}$ The court's powers to interfere with a consensual process must be found in the $A c t$ itself. $^{58}$

\section{vi. Functions of the Court of Appeal}

As I have noted above, ${ }^{59}$ the 1991 Act provides that there is no appeal from the Court of Queen's Bench to the Court of Appeal where all that is involved in the Court of Queen's Bench decision is one of a number of orders providing for a choice of forum. This is to avoid the use of appeals to delay and obstruct arbitrations. Otherwise, the Act does not specifically deal with appeals on procedural matters, which would be left to usual principles, except for s. 8(3), which provides for an appeal to the Court of Appeal, with leave of that court, of the determination by the Court of Queen's Bench of a question of law that arises during the arbitration.

Section 48 of the 1991 Act provides for appeals to the Court of Appeal from Court of Queen's Bench decisions on setting aside applications, appeals and applications for declarations of invalidity. All such appeals require the leave of the Court of Appeal.

SS

56

57

Supra note 40 at 91.

Ibid. at 93.

An Ontario decision leaves open the question whether there can be judicial review under the Ontario Arbitrations Act: Superior Propane Inc. v. Valley Propane (Ottawa) Lid. (1993), O.J. 442

(QL). In my submission, there is no room for judicial review.

This subject is also discussed in Hurlburt, supra note 48, at 188-90.

See III(B)(3)(c) above. 
Section 48 has been said to be ambiguous in its assignment of jurisdiction as between the Court of Queen's Bench and the Court of Appeal. ${ }^{60}$ Section 48 reads as follows:

An appeal from the court's decision in an appeal of an award, an application to set aside an award or an application for a declaration of invalidity may be made to the Court of Appeal of Alberta with leave of that Court.

Grammatically speaking, the section could be read as saying that "an application to set aside an award or an application for a declaration of invalidity ... may be made to the Court of Appeal ...." What it is intended to mean is that "an appeal from the [Court of Queen's Bench's] decision in ... an application to set aside an award ... may be made to the Court of Appeal" and "an appeal from the [Court of Queen's Bench's] decision in ... an application for a declaration of invalidity may be made to the Court of Appeal." While it is unlikely that the section will be construed as requiring that setting aside applications and declaration applications go to the Court of Appeal without going to the Court of Queen's Bench first, this is a point that could usefully be clarified if the Act is amended at any time.

In summary, the $1991 \mathrm{Act}$ is intended to strengthen the arbitration process and restrict supervisory judicial intervention to cases in which intervention is clearly necessary in order to protect a party against unfaimess or illegality. That is the reason for the no-appeal provisions of the Act and for the requirement of leave for appeals to the Court of Appeal from Court of Queen's Bench decisions dealing with awards.

\section{JUDICIAL TREATMENT OF THE NEW ARBITRATION ACTS}

\section{A. GENERAL DISCUSSION}

The 1991 and 1992 Arbitration Acts of Alberta, Ontario, New Brunswick and Saskatchewan are based on the Uniform Arbitration Act and are very similar. While the few differences have to be borne in mind, the similarity is so great that the judicial decisions of each of the four provinces are in most cases applicable to all four. This is a great convenience and is indeed one of the great benefits of having uniform legislation.

The 1991 and 1992 Acts are still very new. Three to four years of history is not very much. The Acts have, however, been considered and applied in a significant number of cases. The Appendix to this paper contains brief summaries of a number of reported and unreported decisions located by a simple computer search, and thus gives an overview of what has happened.

When the 1991 and 1992 Acts were adopted in the four provinces, one great question was whether the courts would accept and apply the policies behind the new Acts, 
particularly the policy of strengthening the arbitration process and limiting judicial supervisory intervention to cases in which it is necessary to protect a party against unfairness or illegality. So far, the actual decisions appear to fit quite well within the structures of the new Acts and the expectations with which they were enacted. While there have been a few dicta suggesting that the ghosts of the old discretions are still with us, there have been more that recognize the primacy of the intention to arbitrate.

Cases under the new Acts which use language that appears to recognize the old discretions are as follows:

1) McCullough v. Peat Marwick Thorne-T.61 The decision was that actions based on conspiracy and defamation fell outside the arbitration clause in the case so that a stay would not be granted. On the first argument, the court appeared to rely on authorities which dealt with the old discretions. On rehearing, however, the court emphasized that the grounds for decision was the interpretation of the arbitration clause, so that it is unlikely that the case will have any precedential effect outside the area of interpretation. This is particularly so in view of the later decision of the Alberta Court of Appeal in Kaverit Steel and Crane Ltd. v. Kone Corporation. ${ }^{62}$ While that case was decided under the International Commercial Arbitration Act, it established that the possible inconvenience of a proposed arbitration did not render the arbitration agreement "null and void, inoperative or incapable of being performed" within the meaning of the latter $A c t$ and suggests that the courts will recognize the primacy of arbitration where an arbitration agreement exists.

2) Willick v. Willick. ${ }^{63}$ In this case, the court said that it continued to have jurisdiction to set aside an award for gross error of law on the face of the record. I have already given reasons for saying that this jurisdiction does not exist in Alberta.

3) Fitz-Andrews v. Meisner. ${ }^{64}$ A party argued that a conflicting action should not be stayed because there was a substantial question of law involved and the court should exercise its discretion in favour of allowing the action to proceed. The court granted the stay, holding correctly that, in considering the authorities, "regard must be had to the fact that they pre-dated the enactment of the current Arbitrations Act." However, the court said that "the onus is upon the person opposing the stay of proceedings to satisfy the Court that, on the whole, the Court proceeding is a better course than arbitration." This is the language of discretion. Section 7(1) of the Ontario (and Alberta) Act uses the language of legal entitlement: it requires that the court grant a stay unless the this case and the Kaverit case in Hurlburt, W.H., "Escape from Arbitration Clauses" (1992) 30 Alta. L. Rev. 1361. 
case falls within one of a specified list of exceptions. The Fitz-Andrews language has not been picked up in later decisions and is not likely to be persuasive in view of the mandatory language of s.7(1) and statements in later decisions that are inconsistent with it.

Cases that have recognized the change in policy of the 1991 and 1992 Acts include the following:

1) In Bakorp Management Ltd. v. Pepsi-Cola Canada Ltd., ${ }^{65}$ Farley J. quoted s. 6, as well as some other provisions, and said "Clearly the Courts should act with great caution before interfering with an arbitration...."

2) In Borowski v. Heinrich Fiedler Perforiertechnik $\mathrm{GmbH}$, Murray J. said that "the theory behind the 1991 Arbitration Act is that if the parties agree to submit their disputes to arbitration then one party should be able to hold the other to it," 66 and pointed out that s. 6 prohibits the court from intervening in matters governed by the $A c t$, with certain exceptions.

It will be useful to refer to two decisions of Blair J. of the Ontario Court of Justice, General Division, as these seem persuasive in themselves and as they have been picked up by later decisions. These are Ontario Hydro v. Denison Mines Ltd. ${ }^{67}$ and Deluce Holdings Inc. v. Air Canada. ${ }^{68}$ In the Ontario Hydro case, Blair J. said this at pages 5-6:

[The regime enacted by the new Act] is designed, in my view, to encourage parties to resort to arbitration as a method of resolving their disputes in commercial and other matters, and to require them to hold to that course once they have agreed to do so.

In this latter respect, the new Act entrenches the primacy of arbitration proceedings over judicial proceedings, once the parties have entered into an arbitration agreement, by directing the court, generally not to intervene, and by establishing a "presumptive" stay of court proceedings in favour of arbitration.

This passage epitomizes the intention of the framers of the new Acts. Later, at pages 6 and 7, Blair J. quoted s. 6 and s. 7(1) of the 1991 Act and said that now, "the court is only entitled to refuse the stay in certain limited circumstances as enumerated in $\mathbf{s}$. 7(2)," as compared with the discretionary words of the old Act.

A comparison of the results of the Ontario Hydro and Air Canada cases is useful in the determination of the boundary within which an arbitration should be allowed to proceed without interference. 
In Ontario Hydro, Blair J. held that a dispute over a claim for rectification of an agreement fell within an arbitration clause saying that "all disputes arising in connection with this agreement shall be finally settled [by arbitration] ...." This allows the parties to give an arbitrator power over the very agreement that created their jurisdiction. ${ }^{69}$ It also allows the parties to give the arbitrator power to give an equitable remedy that has been regarded peculiar to the superior courts. ${ }^{70}$ Under traditional thinking, this would be very strong medicine indeed.

Air Canada was on the other side of the line. The arbitration clause provided for the arbitration of the purchase price under an option to purchase an employee's shares in a corporation. The share owner-optionor alleged that the optionee had procured the optionor's dismissal in order to activate the option and that doing so, in the circumstances, constituted oppression under the Canada Business Corporations Act. Blair J. refused to stay the oppression action and instead made an interim order staying the arbitration pending the disposition of the action, holding that the real subject matter of the dispute was not the share price which the parties had agreed to arbitrate "but rather one which strikes at the very underpinning of the contractual mechanism itself" and which therefore lay beyond the scope of s. 7(1) of the Arbitration Act 1991.

In Hyundai Auto Canada Inc. v. Dayhu Investments Ltd ${ }^{71}$ Rosenberg J. of the same court drew a similar distinction. Where an arbitration clause provided for the arbitration of the fair market value of leased land for the purpose of an option to purchase, Rosenberg J. held that substantial doubts as to whether the option had been exercised were grounds for staying the arbitration.

In the Air Canada case, an oppression cause of action conferred by the Canada Business Corporations Act, if it existed, might mean that the basic right on which the arbitration was founded, but which was not referred to arbitration, did not exist. In the Hyundai case, the basis of the claim upon which the proposed arbitration was founded, and which was not referred to arbitration, was in doubt. These decisions do not appear to be inconsistent with either the spirit or letter of the new Acts. Section 7(1), which mandates a stay of conflicting court actions, applies only if the court action is "in respect of a matter in dispute to be submitted to arbitration under the agreement." It would be going a long way to say that submission of the purchase price of shares or land to arbitration gives the arbitrator power to determine whether there has been CBCA oppression or whether an option has been validly accepted. These are questions far removed from what was submitted.

The trend of the decisions is towards recognizing the "primacy" of arbitration once there is an agreement to arbitrate.

This is consistent with the Alberta $A c t$, s. 17(1), which gives an arbitral tribunal power to rule on its own jurisdiction.

This is consistent with the Alberta Act, s. 31 which specifically confers power to give equitable remedies.

" [1993] OJ. No. 1178 (Gen. Div.) (QL). 


\section{B. INTERPRETATION OF ARBITRATION CLAUSES}

The interpretation of arbitration clauses by the courts since the introduction of the new Acts does not suggest that narrow interpretation is being used with a view to excluding arbitration; the principles of interpretation applied seem to be consistent with ordinary contract interpretation and to be, if anything, rather favourable to arbitration.

McCulloch v. Peat Marwich Thorne-T, ${ }^{72}$ it is true, gave a fairly narrow interpretation to the arbitration clause involved in the case, which covered "any dispute ... relating to the construction, meaning or effect of anything in this agreement or the rights or liabilities of any party pursuant to this agreement." The plaintiff claimed that the defendants had not only breached the agreement but had committed other wrongs. It is arguable that on the precise wording of the clause, claims for wrongs other than breach of the contract are outside it, so that the decision need not be taken to establish a principle of narrow construction. On the other hand, it is not clear why the court did not stay the action insofar as it was based on rights and liabilities under the contract and allow it to proceed insofar as the other claims are concerned, which is what s. 7(5) contemplates. If an arbitration can be stopped by adding claims that are outside the arbitration agreement, ingenious plaintiffs who want to avoid arbitration will add them. ${ }^{73}$ It does not so far appear that there is a judicial trend towards permitting that to happen.

In other cases, the courts have interpreted clauses more broadly:

- In Kaverit Steel and Crane Ltd. v. Kone Corp., Kerans J.A. held that a clause providing for the arbitration of disputes "arising out of or in connection with" the contract included a dispute "if either claimant or defendant relies on the existence of a contractual obligation as a necessary element to create the claim, or to defeat it." ${ }^{14}$ (This was an ICAA case but the reasoning applies equally to an Arbitration Act case.)

- In Kvaerner Enviropower Inc. v. Tanar Industries Ltd. ${ }^{75}$ the arbitration clause provided that "any controversy between the parties" (who were contractor and subcontractor) "shall be decided by arbitration." The Court of Queen's Bench held that, among other things, "slander of title/wrongful lien and breach of contract ... in filing liens which lacked any basis in law or fact" $^{\text {"76 }}$ were "controversies" that fell within the clause, being "differences arising out of commercial, legal relationships and in the context of the contract

73 As Kerans J.A. put it in Kaverit Steel \& Crane Lid. v. Kone Corp., supra note 62 at 353 "the agreement to arbitrate should be honoured and enforced whether or not the plaintiff displayed great imagination in the pleadings."

$74 \quad$ Ibid. at 351. 
at bar." ${ }^{277}$ The Court of Appeal dismissed the appeal. (This was an ICAA case, but the reasoning applies equally to an Arbitration Act case.)

- In Pulvermacher v. Pulvermacher, ${ }^{78}$ although the plaintiff's action was based on what he characterized as a conspiracy by the other shareholders to prevent him from getting full value for his shares, the Saskatchewan Court of Queen's Bench held that the real issue was whether the plaintiff should receive full market value, which was within the arbitration clause, and granted a stay.

- In Bakorp Management Ltd., a party brought an action alleging wrongdoing in connection with matters which would affect the purchase price which the arbitrator was to determine. The action was stayed, and the court drew particular attention to s. 6 of the Arbitration Act (court intervention limited) as well as to s. 7(1) (stay) and s. 17(1) (which gives an arbitral tribunal power to rule on its own jurisdiction).

- In Scotia Realty Ltd. v. Olympia and York, ${ }^{79}$ the court held that the arbitration clause (actually a Scott v. Avery clause) included disputes about the effect of an amendment to the lease in which the clause appeared, and the court stayed an action based on the amendment.

On the whole, the decisions reviewed suggest that the courts have given full scope to arbitration clauses under the usual contract-interpretation process and are likely to continue to do so.

\section{RELATIONSHIP OF ARBITRATION TO MECHANICS' AND BUILDERS' LIEN LEGISLATION}

Provincial lien legislation typically confers a lien on those who provide services and materials for improvements on real property and states how the validity and amount of liens is to be determined and how liens are to be secured and enforced. This legislation has not been well articulated with the Arbitration Acts, and the relationship between them is not clear from a reading of the respective acts.

Section 3 of the Alberta Builders' Lien Act, for example, provides that "an agreement by any person that ... the remedies provided by [this Act] are not to be available for his benefit is against public policy and void." ${ }^{180}$ In Bird Construction Co. v. Tri-City Interiors Ltd. ${ }^{81}$ the Alberta Court of Appeal, however, held that bringing a proceeding under the BLA does not waive a right to arbitration and proceeded to stay the lien

$n \quad$ lbid. at $188-89$.

7n [1994] S.J. No. 595 (Q.B.) (QL).

79 [1992] O.J. No. 811 (Gen. Div.) (QL).

$\$ \quad$ R.S.A. 1980 , c. B-12, s. 3.

81 (2 May 1994), Edmonton 9303-0250-AC/9303-0249-AC (Alta. C.A.). Because Tri-City commenced the lien action it could not apply for a stay of the action under $5.7(1)$ of the Arbitration Act, but the Court of Appeal was willing to exercise its inherent powers to grant the stay. 
proceeding pending the arbitration, thus reading the two Acts together. In a later case, Kerans J.A., speaking for the Court, said:

\begin{abstract}
Similarly, we are of the view that s. 3 of the Builders' Lien Act should not be interpreted to prohibit arbitration of disputes involving lien claims. While the words might reasonably bear that interpretation, we are all of the view that it was not the purpose of the Act and that it would work considerable mischief were we to put that interpretation on $\mathrm{s.} 3^{82}$
\end{abstract}

The special significance of this decision and the Bird Construction decision is that, as the emphasized words indicate, the Court of Appeal made a policy choice in favour of supporting arbitration.

The Saskatchewan Court of Appeal came to a similar conclusion in BWV Investments Ltd. v. Saskferco Products Inc. ${ }^{83}$ That was a case under the Saskatchewan ICAA, but the court referred to the "Canadian position" under the Arbitration Act as being that "matters in dispute between the parties to arbitration are stayed pending the outcome of the arbitration." ${ }^{184}$

In this instance, the courts, where the wording of the legislation left a policy choice open, have opted to support arbitration.

\title{
D. COURT SUPERVISION OF AWARDS
}

\section{Setting aside}

Under s. 45 of the Alberta Act (s. 46 of the Ontario Act), the trial court of general jurisdiction has power to set aside an award on any of a number of different grounds. The only case in the Appendix that deals with this subject is Environmental Export International of Canada Inc. v. Success International Inc. ${ }^{85}$ In that case the court held that holding a hearing in the absence of a party did not amount to unfair or unequal treatment or bias, in circumstances in which it appeared that the applicant had advised the arbitrator that it would not attend and appeared to have abandoned the arbitration, and in which the arbitrator had tried to notify the applicant that the hearing would proceed (though the notice went to the wrong fax number). At its lowest, this case does not suggest that the courts will use the setting aside power without significant grounds.

Kvaerner Enviropower Inc. v. Tanar Industries Ltd., supra note 75 at 366 (Alta. C.A.) [emphasis added]. This case was decided under the International Commercial Arbitration Act but there is no observable reason why it would not apply equally where the Arbitration Act applies, and, indeed, the Bird Construction case was an Arbitration Act case.

s4 The Ontario Court of Appeal held in Automatic Systems Inc. v. Bracknell Corp. (1994), 18 O.R (3d) 257 that the Ontario Construction Liens Act did not preclude arbitration under the Ontario ICAA. This may signify a court attitude but is not otherwise of assistance in other provinces, as the Ontario CLA did provide for arbitration under the Arbitration Act, thus providing a different legal context for the decision. 


\section{Appeal}

It is not clear what the courts will require in order to grant leave to appeal from an award on a question of law. The factors ${ }^{86}$ set out in Alberta's s. 44(2) (Ontario's s. 45(1)) have not been discussed. In three cases, the Ontario courts have held that the factors have been satisfied, but without giving reasons for saying so. ${ }^{87}$ This may indicate that the factors will not have a significant screening effect, but it is too early to discern a trend.

Once leave has been granted, the courts have considered themselves free to substitute their own views about the question of law involved for those of the arbitrator: the "correctness" or "judicial" standard of review is being applied. This is explicit in Willick v. Willick and in Petrolon Distribution Inc. v. Petro-Lon Canada Ltd. ${ }^{88}$ and it is implicit in other decisions. It is consistent with the Acts. Several of the judgments, however, take the arbitrator's reasoning very seriously and are influenced by it.

The cases do not disclose any tendency to use the appeal power to undercut arbitration. Indeed, Pachanga Energy Inc. v. Mobil Investments Canada Inc., Willick v. Willick, and Aztec Construction Ltd. v. Frocan Industrial Contractors Ltd. et al. have extended s. 44(3) of the Alberta Act and thus reduced the area of appeals on law. The courts have performed their function of supervising the law applied in the cases that have been appealed and, in the process, have given due regard to the reasoning of the arbitrators.

\section{E. CONCLUSION}

As has been noted, the $1991 \mathrm{Act}$ and its counterparts in other provinces struck a new balance between courts and arbitrators. Broad court discretions are out. Court powers of assistance and supervision in specified circumstances are in.

The courts have recognized and accepted the policy change. They have given primacy to the agreement of the parties to arbitrate their differences. With remarkably few aberrations, they have applied the spirit and the letter of the Acts.

With one or two exceptions, this paper has not referred to decisions on the International Commercial Arbitration Acts. Many of them are relevant, sometimes directly and sometimes by analogy, to a discussion of the judicial treatment of the Arbitration Acts, but an examination of those decisions is beyond the scope of this paper. It is enough to say here that the courts have also, in general, accepted the ICAAs

$\mathbf{8 6}$

The court must be "satisfied that (a) the importance to the parties of the matters at stake in the arbitration justifies an appeal, and (b) determination of the question of law at issue will significantly affect the rights of the parties."

87 Metropolitan School Board v. Daniels Lakeshore Corp. (1993), O.J. No. 2375 (Gen. Div.) (QL); Charles v. Saveway Gas \& Fuels Lid. (1993), O.J. No. 833 (Gen. Div.) (QL); Labourers International Union of North America, Local 183 v. Carpenters' and Allied Workers Local 27 (1994), O.J. No. 274 (Gen. Div.) (QL).

89 (1995), O.J. No. 1142 (QL) (Gen. Div.). 
and the policies behind them and that the ICAA cases tend to support the conclusion drawn here.

\section{SIGNIFICANCE OF THE 1991 ACT FOR DRAFTERS}

\section{A. INTRODUCTION}

The 1991 Act makes it more difficult to escape from arbitration into litigation. ${ }^{89}$ That is salutary, but it makes it more desirable than ever to take steps to ensure that arbitration clauses and agreements promote the interests of the parties who enter into them. The courts are less likely to bail out an incautious drafter than they were under the old Acts.

That is one reason why drafters should take a fresh look at the clauses they use. Another is that the 1991 Act sets out much more procedure than the old Acts did. It thus fills in a good many blanks. However, it is incautious to accept even the most well-designed pig without looking inside the poke.

Arbitration clauses look like legal boilerplate. Parties do not negotiate contracts with a view to having disputes. Parties who have negotiated a significant contract are not likely to want to jeopardize it by opening up a new topic for negotiation. But when a dispute arises, an arbitration clause can become very important to the parties, so that it behooves drafters to understand its effect.

The Alberta Law Reform Institute is in the late stages of preparing a Reference Guide for drafters of arbitration clauses and agreements. This paper cannot replicate the function of the Reference Guide, but will ask some questiuns that drafters may want to consider.

\section{B. SCOPE OF AN ARBITRATION CLAUSE}

What disputes do the parties want settled by arbitration? Do they want to arbitrate the rent to be paid under a renewal of lease? Do they want to arbitrate any dispute under a principal contract? Do they want to arbitrate any and all disputes that may arise from their relationship, whether a claim is made under the contract or in tort? Should steps be taken to ensure that all parties necessary to a complete solution of a problem (e.g., the owner, architect and contractor, or owner, contractor and subcontractor) will be brought into the arbitration? Drafters should consider questions such as these.

The question of scope is crucial. It is entirely within the parties' control. The Act has nothing to say about it. 


\section{NUMBER AND QUALIFICATIONS OF ARBITRATORS}

Section 9 of the Act provides for one arbitrator in the absence of agreement. A single-member tribunal is cheap. It is efficient in the sense that it makes it easier to convene meetings and make decisions. Is it right for disputes under the agreement being drafted? Or should there be three? The only qualifications stipulated by the Act are independence and impartiality. Are other qualifications needed for the adjudication of disputes under the clause being drafted?

How should the arbitrator or arbitrators be appointed? Appointment by agreement is best. But what if there is no agreement? Section 10 of the Act gives the Court of Queen's Bench a power to appoint arbitrators in default of agreement or other effective machinery. Is that suitable? Should consideration be given to appointment by an independent functionary?

\section{PROCEDURE}

The Act has a good many specific provisions about procedure, and it clothes the arbitrator with power to determine pretty well everything else. The parties can, however, vary or exclude all procedures laid down by the Act and can give any directions they want to the arbitrator, subject always to the statutory duty of fairness and equal treatment. So two questions arise. First, are the procedural provisions of the Act suitable for the case in hand? For example, should the arbitrator be bound by the rules of evidence (s. 21(1) of the Act says no)? Should there be examinations for discovery either as of right or as a discretionary power of the arbitrator (s. 25(6) gives a discretionary power)? Second, are there any directions that should be given to the arbitrator, such as time limits or a requirement of an early prehearing conference?

A drafter may accept the Act in its entirety. They may accept it in general but vary or exclude some specific provision. Or they may substitute a whole set of provisions or rules to govern arbitrations under the arbitration clause. The appropriateness of any of these approaches is determined by the whole of the circumstances, including the kinds and magnitude of disputes that are likely to arise under the arbitration clause or agreement under consideration.

\section{E. APPEALS}

What court intervention in awards do the parties want? They cannot contract out of the Court of Queen's Bench's power to set aside awards under s. 45 and they cannot contract out of an appeal to the Court of Queen's Bench under s. 44(2), with leave, on a question of law. Do the parties want an appeal as of right on a question of law? Do they want an appeal on fact or mixed law and fact? If so, they can have them under s. 44(1), but they must say so. Or, under s. 44(3) they can avoid an appeal on law by expressly referring a question of law to the arbitrator. If they want to eschew law entirely, they can override s. 31 by providing that the arbitrator is not bound by law, thus undercutting, or at least minimizing, the scope of an appeal on law, but this would be an heroic measure that should not be undertaken lightly. 


\section{F. CONCLUSION}

Arbitration can be a good thing. But it would be prudent for drafters to review arbitration clauses and agreements to see that the interaction of the Act with a clause or agreement will make it a good thing for their clients.

\section{GENERAL CONCLUSION}

The 1991 Arbitration Act has articulated clear policies of party control, fairness and efficiency. It has provided a more extensive procedural framework, though this is under the control of the parties. It has taken steps to minimize tactics of obstruction and delay. It has strengthened the autonomy of the arbitration process by doing away with the general discretionary controls previously exercised by the courts, while leaving the courts a major role in ensuring the integrity and legality of the process. Its policies have, by and large, been recognized and applied by the courts.

The $1991 \mathrm{Act}$ will not change the essential nature of arbitration. However, after a time, the change of bottle should have an effect on the wine. Perhaps someone will undertake an investigation to see whether it does. 


\section{APPENDIX}

An extensive sample of Alberta, Ontario and Saskatchewan decisions on the 1991 and 1992 Arbitration Acts:

\section{ONTARIO DECISIONS}

\begin{tabular}{lll}
\hline Subject & Case & Decision \\
\hline Stay & $\begin{array}{l}\text { Scotia Realty Ltd. v. } \\
\text { Corp. (1992), 9 O.R. (3d) } \\
414 \text { (Gen. Div.). }\end{array}$ & $\begin{array}{l}\text { Held that under the old Act a Scott v. Avery clause } \\
\text { contemplated that all disputes as to participation rent, } \\
\text { including a dispute about an alleged amendment to the } \\
\text { lease, would be arbitrated, and the landlord's } \\
\text { application for interpretation of rights was stayed. The } \\
\text { court said that, since the landlord's application in effect } \\
\text { sought to preempt arbitration for the following year, } \\
\text { which would have been conducted under the 1991 } A c t,\end{array}$ \\
& it was useful to note that s. 7(1) of that Act provides \\
that litigation "shall" be stayed and enumerates in \\
s. 7(2) very narrow grounds of exception, none of \\
which would apply in the instant case. The court \\
referred to $s .8(2)$ (determination of questions of law) \\
and said "This enactment gives effect to the view of \\
Laskin J. in Deuterium that there should be no return to \\
the jealous guarding of the court's jurisdiction against \\
encroachment by arbitration."
\end{tabular}

Comment: The dicta suggest that the courts will recognize and apply the policy of the new Acts.

Fitz-Andrews v. Meisner.

[1993] O.J. No. 191

(Gen. Div.) (QL)

Stay of conflicting action granted. Authorities before new $A c t$ do not apply. But: case says the onus is on respondent to show Court proceedings more favourable.

Comment: Result is appropriate, but the "court proceedings more appropriate" criterion does not recognize the effect of s. 7 .

Ontario Hydro v.

Denison Mines Led., [1992] O.J. No. 2948

(Gen. Div.) (QL)
Stay granted. New Act "entrenches the primacy of arbitration proceedings over judicial proceedings" once there is an arbitration agreement. Claim for rectification of main agreement, in view of expanded and extended powers under new $A c t$, is a "dispute in connection with the agreement."

Comment: This is an important case, recognizing, in general terms and by including rectification, the policy of the new Acts in fovour of strengthening the arbitration process. 


\begin{tabular}{|c|c|c|}
\hline Subject & Case & Decision \\
\hline \multirow[t]{2}{*}{ Stay } & $\begin{array}{l}\text { Deluce Holdings Inc. v. } \\
\text { Air Canada (1992), } 12 \\
\text { O.R. (3d) } 131 \text { (Gen. } \\
\text { Div.). }\end{array}$ & $\begin{array}{l}\text { Stay of action refused. Arbitration clause was for } \\
\text { valuation of shares in purchase under option. Plaintiff } \\
\text { claimed that defendant had engaged in oppressive } \\
\text { conduct under } C B C A \text { in bringing about the event } \\
\text { triggering the option. Held that the real subject matter is } \\
\text { not one the parties have agreed to submit to arbitration } \\
\text { but one which strikes at underpinning of the contractual } \\
\text { mechanism and is beyond s. } 7 \text { of the Arbitration Act. } \\
\text { There is equitable jurisdiction to restrain arbitration } \\
\text { where foundation of the arbitration agreement is under } \\
\text { attack, so injunction against arbitration granted. }\end{array}$ \\
\hline & & $\begin{array}{l}\text { Comment: This case establishes a limit to the operation } \\
\text { of the new Acts but is not inconsistent with them. Note } \\
\text { that it was decided by Blair J., who also decided the } \\
\text { Ontario Hydro case. }\end{array}$ \\
\hline
\end{tabular}

Stay

Dimarino v. United

Imaging Inc., [1992] O.J.

No. 2494 (Gen. Div.)

(QL)
All disputes were within the arbitration agreement.

Bare allegation of invalidity of the principal agreement not enough to justify a stay.

Comment: This case gives appropriate recognition to the status of arbitration as the chosen forum.

Decision refers both to the ICAA and the 1991 Arbitration Act.

1) Party "may" give notice and dispute "shall" be referred is mandatory if notice is given.

2) Stay resisted on grounds that court had to determine whether there was a contract. Court said that whether defendant was in breach should not be the subject matter of a motion and intent to arbitrate continued in face of allegation of breach of contract. Stay of competing action granted.

Comment: The case appears reasonably supportive of arbitration but is not particularly significant. 


\begin{tabular}{|c|c|c|}
\hline Subject & Case & Decision \\
\hline Stay & $\begin{array}{l}\text { ABN Amro Bank Canada } \\
\text { v. Krupp MaK } \\
\text { Maschinenbau GMBH } \\
\text { (1994), } 21 \text { O.R. (3d) } 511 \\
\text { (Gen. Div.). }\end{array}$ & $\begin{array}{l}\text { This is an ICAA case. A dictum p. } 16 \text { notes that s. } 7(1) \\
\text { of } 1991 \text { Arbitration Act says "shall stay" instead of } \\
\text { "may," and it can be argued use of "may" in s. } 7(2) \text { has } \\
\text { narrowed the court's discretion by specification of } \\
\text { grounds on which stay may be refused. }\end{array}$ \\
\hline
\end{tabular}

Comment: The dictum referred to recognizes the change in policy of the new Act with respect to stays.

Bakorp Management Lid. v. Pepsi-Cola Canada Lid., [1994] O.J. No. 873 (Gen. Div.) (QL)
Application for stay. Arbitration of purchase price. Everything inconsistent with the arbitration clause, including allegations of conspiracy affecting what went into determining the price, stayed. References to s. 6 and others and to Ontario Hydro. "The Courts should act with great caution before interfering with an arbitration ..." "Where matters in dispute in litigation are inextricably bound up with matters which the parties have agreed to arbitration, the Courts will refuse to permit such multiplicity of proceedings and will stay the litigation ...."

Comment: This is another significant case. It picks up on Ontario Hydro and adopts similar reasoning. 


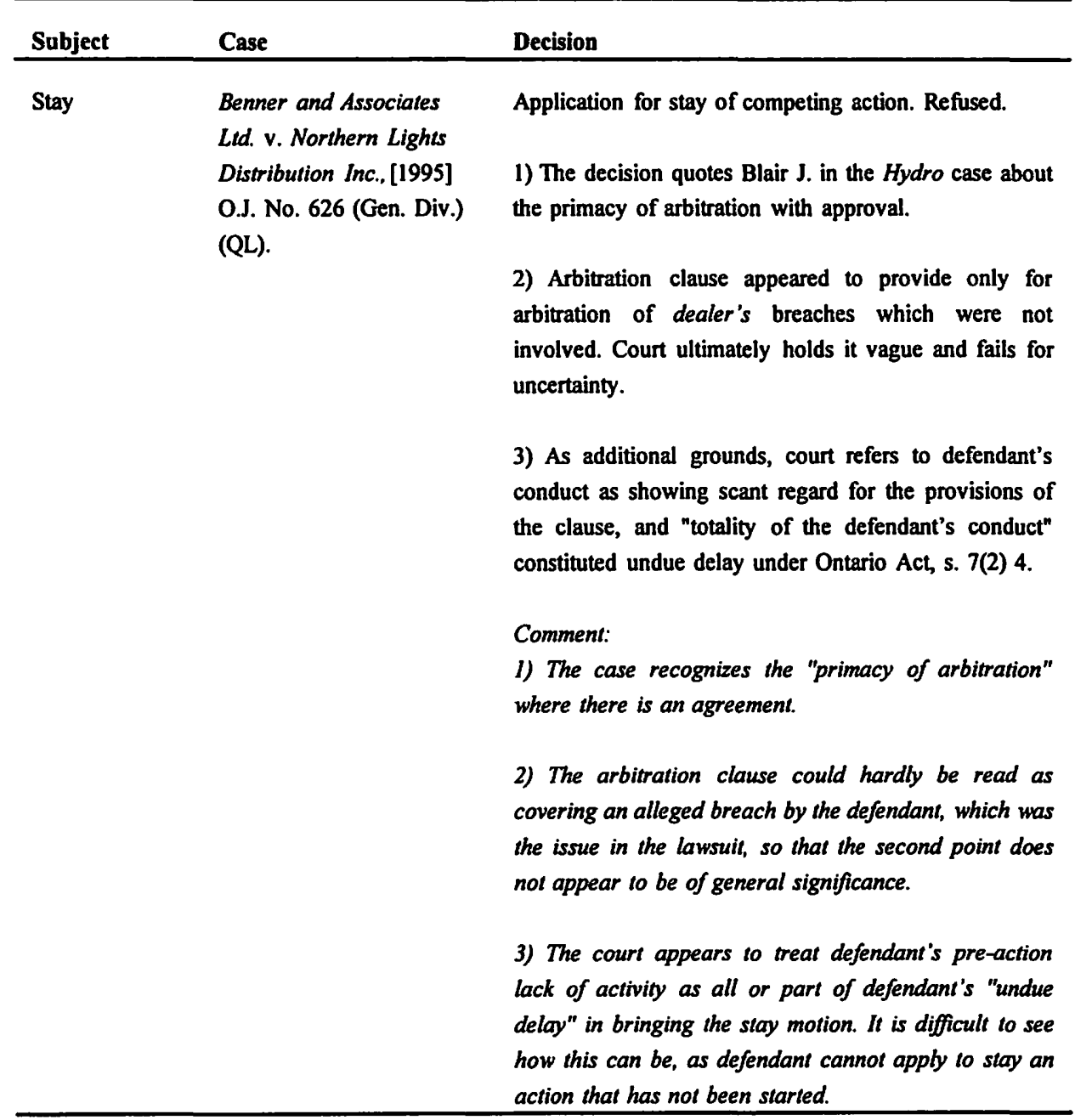

Entitlement Jevco Insurance Co. v. Canadian General Insurance Co. (1993), 14 O.R. (3d) 545 (Gen. Div.).
Application for appointment by arbitrator. Jevco paid no-fault benefits to its insured motorcyclist and claimed indemnity from CG, insurer of the other vehicle. Jevco's insured sued CG's insured. This was not an "unsettled claim against the insurer" which would have made arbitration premature. Appeal from dismissal of application allowed.

Comment: This case is probably not significant but at least shows a willingness to let an arbitration proceed over opposition. 


\begin{tabular}{|c|c|c|}
\hline Subject & Case & Decision \\
\hline \multirow[t]{4}{*}{ Entitlement } & $\begin{array}{l}\text { Buck Bros. Lid. v. } \\
\text { Frontenac Builders Ltd. } \\
\text { (1994), } 19 \text { O.R. (3d) } 97\end{array}$ & $\begin{array}{l}\text { Application below was for a declaration that applicant } \\
\text { was entitled to arbitration. }\end{array}$ \\
\hline & (C.A.). & $\begin{array}{l}\text { The General Division order was that jurisdictional facts } \\
\text { be determined by arbitrator. }\end{array}$ \\
\hline & & $\begin{array}{l}\text { Application in C.A. was to quash appeal. C.A. merely } \\
\text { held that the order was a final order for appeal purposes } \\
\text { and refused to quash. }\end{array}$ \\
\hline & & $\begin{array}{l}\text { Comment: This decision is not significant, although the } \\
\text { result of the appeal may be. }\end{array}$ \\
\hline \multirow[t]{2}{*}{ Entitlement } & $\begin{array}{l}\text { Hyundai Auto Canada } \\
\text { Inc. v. Dayhu Investments }\end{array}$ & Application for appointment of arbitrator. Stayed. \\
\hline & $\begin{array}{l}\text { Led., [1993] O.J. No. } 1178 \\
\text { (Gen. Div.) (QL). }\end{array}$ & $\begin{array}{l}\text { The arbitration agreement was for determination of } \\
\text { market value of land for purchase option. But there was } \\
\text { a strong prima facie case option was not properly } \\
\text { exercised. Balance of convenience favoured not going } \\
\text { ahead with the arbitration until preliminary matters } \\
\text { settled. }\end{array}$ \\
\hline
\end{tabular}

Quotes Ontario Hydro case as to primacy of arbitration where parties have agreed.

Comment: Like the Air Canada case, this case establishes a limit to the operation of the new Acts but is not inconsistent with them. It pays close attention to the Ontario Hydro and Air Canada cases. 


\begin{tabular}{|c|c|c|}
\hline Subject & Case & Decision \\
\hline \multirow[t]{7}{*}{$\begin{array}{l}\text { Leave to } \\
\text { appeal }\end{array}$} & $\begin{array}{l}\text { Metropolitan School } \\
\text { Board v. Daniels }\end{array}$ & Leave to appeal granted. \\
\hline & Lakeshore Corp, [1993] & 1) $1991 \mathrm{Act}$ applied to an arbitration started in 1992. \\
\hline & O.J. No. 2375 (Gen. & \\
\hline & Div.) (QL). & $\begin{array}{l}\text { 2) An agreement that award is final and binding does } \\
\text { not exclude s. } 45(1) \text { appeal (Ontario s. } 45(1) \text { is a } \\
\text { counterpart of Alberta s. } 44(2) \text {, but differences between } \\
\text { them make this point irrelevant to Alberta). }\end{array}$ \\
\hline & & $\begin{array}{l}\text { 3) Whether arbitrator could consider a factor not } \\
\text { mentioned in the agreement is a question of law. }\end{array}$ \\
\hline & & 4) The leave criteria were met. (No reasons.) \\
\hline & & $\begin{array}{l}\text { Comment: This case is a straightforward application of } \\
\text { the } 1991 \text { Act. Reasons for holding that the leave criteria } \\
\text { were met would have been useful. }\end{array}$ \\
\hline
\end{tabular}

Leave to Charles v. Saveway Gas Leave granted. The decision sets out some questions appeal \& Fuels Ltd. [1993] O.J. that look like questions of law. It holds that the leave No. 833 (Gen. Div.) criteria are satisfied without giving reasons.

(QL).

Comment: The case is not significant. Reasons for holding that the leave criteria uere met would have been useful.

Waiver of appeal
Superior Propane Inc. v. Valley Propane (Ottawa) Ltd. [1992] O.J. No. 2773 (Gen. Div.) (QL).
Leave to appeal refused. Parties had a right to agree that decision was final and binding.

Comment: This decision is not relevant to Alberta, as Alberta's appeal on a question of law, though subject to leave, is otherwise as of right and contained in a section that cannot be excluded or varied. 


\begin{tabular}{|c|c|c|}
\hline Subject & Case & Decision \\
\hline $\begin{array}{l}\text { 1) Appeal } \\
\text { from refusal of } \\
\text { leave to } \\
\text { appeal. }\end{array}$ & $\begin{array}{l}\text { Superior Propane Inc. v. } \\
\text { Valley Propane (Ottawa) } \\
\text { Lid., [1993] O.J. No. } 442 \\
\text { (QL). }\end{array}$ & $\begin{array}{l}\text { 1) There is no specific finding that agreement that the } \\
\text { arbitrator's decision will be final and binding waives an } \\
\text { appeal, but tenor and finding concerning judicial review } \\
\text { strongly suggest that it does. (This is not relevant to } \\
\text { Alberta for reasons given above.) }\end{array}$ \\
\hline \multirow[t]{3}{*}{$\begin{array}{l}\text { 2) Availability } \\
\text { of Judicial } \\
\text { Review. }\end{array}$} & $\begin{array}{l}\text { (This is said to be } \\
\text { General Division, but it } \\
\text { includes appeal from the } \\
\text { General Division decision }\end{array}$ & $\begin{array}{l}\text { 2) There is no appeal from a refusal to grant leave to } \\
\text { appeal. }\end{array}$ \\
\hline & above.) & $\begin{array}{l}\text { 3) Commercial arbitration is for expediency, reduction } \\
\text { of cost, avoidance of protracted litigation. Where parties } \\
\text { agree decision will be final and binding, not open to } \\
\text { judicial review unless arbitrator has acted improperly. } \\
\text { (Did not deal with issue as to whether there is a right to } \\
\text { judicial review when there is a right to appeal.) }\end{array}$ \\
\hline & & $\begin{array}{l}\text { Comment: Much of the decision is about whether an } \\
\text { agreement that an arbitrator's decision is final and } \\
\text { binding waives an appeal, which is irrelevant to } \\
\text { Alberta. The decision that there is no appeal from a } \\
\text { refusal of leave to appeal is useful in limiting the extent } \\
\text { to which court proceedings can add to the cost and } \\
\text { delay of arbitrations. The reference to the possibility of } \\
\text { judicial review apart from the appeal processes } \\
\text { provided by the Acts is unfortunate. }\end{array}$ \\
\hline
\end{tabular}

Right of appeal
Bramalea v. T. Eaton Co., [1994] O.J. No. 38 (Gen. Div.) (QL).
1) Agreement provided that the arbitrator's award would be final and binding. This prohibited an appeal. (For reasons given above, this decision is not relevant to Alberta.)

2) The arbitration agreement permitted a party to "proceed on an issue of law should such arise in the context of the proceedings." This applied only to issues of law arising during the hearings.

Comment: The first point of decision is of little significance to Alberta. The second point of decision might indicate a willingness to interpret language so as to support the parties' agreement to arbitrate. 


\begin{tabular}{|c|c|c|}
\hline Subject & Case & Decision \\
\hline \multirow[t]{4}{*}{$\begin{array}{l}\text { Right of } \\
\text { appeal } \\
\text { Scope and } \\
\text { standard of } \\
\text { appeal }\end{array}$} & $\begin{array}{l}\text { Labourer's International } \\
\text { Union of North America, } \\
\text { Local } 183 \text { v. Carpenter's } \\
\text { and Allied Workers Local } \\
27 \text { [1994] O.J. No. 274, } \\
\text { (Gen. Div.) (QL). }\end{array}$ & $\begin{array}{l}\text { 1) Held that agreement that award is "final and binding" } \\
\text { applies only while the award is unchallenged and does } \\
\text { not preclude an appeal. Refuses to follow Superior } \\
\text { Propane. (This is not relevant to Alberta, for reasons } \\
\text { given above.) }\end{array}$ \\
\hline & & 2) Misinterpretation of a word is an error of law. \\
\hline & & $\begin{array}{l}\text { 3) The leave-to-appeal factors were satisfied. (No } \\
\text { reasons.) }\end{array}$ \\
\hline & & $\begin{array}{l}\text { Comment: The first point is not relevant to Alberta. The } \\
\text { second appears to be usual doctrine. Reasons for } \\
\text { holding that the factors were satisfied would have been } \\
\text { useful. The case does not appear to have much general } \\
\text { significance. }\end{array}$ \\
\hline
\end{tabular}

Appeal Jevco Insurance Co. v Arbitration between insurers as to whether Insurer Halifax Insurance Co., was entitled to indemnification by Insurer B for no-fault [1994] O.J. No. 3024 benefits paid by $A$, which depended on relative (Gen. Div.) (QL). liabilities of A's and B's insureds. Arbitrator applied rule saying that going through red light meant $100 \%$ liability and ignored rule saying that left turn in face of oncoming vehicle meant $100 \%$ liability. Another rule would have made it $50 / 50$ in such circumstances. Appeal allowed.

Comment: This case appears to be an appropriate exercise of the appeal function.

Jevco Insurance Co. v.

Prudential Insurance Co., [1995] O.J. No. 919

(Gen. Div.) (QL).
The question on appeal was whether the right of a motorcyclist's insurer to be indemnified "in relation to" no-fault benefits included indemnification for costs of a medical examination. The whole discussion is about the construction of those words. There is some deference to the particular arbitrator, but this does not seem to be determinative.

Comment: This case appears to be an appropriate exercise of the appeal function. 


\begin{tabular}{|c|c|c|}
\hline Subject & Case & Decision \\
\hline \multirow[t]{3}{*}{$\begin{array}{l}\text { Setting aside } \\
\text { award }\end{array}$} & $\begin{array}{l}\text { Environmental Export } \\
\text { International of Canada } \\
\text { Inc. v. Success }\end{array}$ & $\begin{array}{l}\text { Application to set aside awards and remove arbitrator } \\
\text { on grounds of bias. }\end{array}$ \\
\hline & $\begin{array}{l}\text { International Inc.. [1995] } \\
\text { O.J. No. } 453 \text { (Gen. Div.) } \\
\text { (QL). }\end{array}$ & $\begin{array}{l}\text { 1) On merits, allegations in detail were groundless. } \\
\text { Major one: hearing was scheduled; EEI launched court } \\
\text { application against arbitrator's evidence direction and } \\
\text { advised arbitrator that it would not attend } 28 \text { November } \\
\text { hearing and was cancelling subpoenas. Arbitrator's } \\
\text { reply that he was proceeding was faxed to wrong } \\
\text { number. EEI did not appear at November } 28 \text { hearing. } \\
\text { Court found that it had abandoned proceeding. Holding } \\
\text { the hearing and making award in EEI's absence was not } \\
\text { unfair and unequal treatment or bias. }\end{array}$ \\
\hline & & $\begin{array}{l}\text { 2) One "award" was disposition of EEl's request that } \\
\text { Success answer questions. Held that there is no } \\
\text { provision for appeal from evidence direction and that it } \\
\text { would be a "serious reproach" to the system to make } \\
\text { one. }\end{array}$ \\
\hline & & $\begin{array}{l}\text { Comment: Case shows unwillingness to interfere with } \\
\text { an award and arbitrator on trivial grounds. It also } \\
\text { shows unwillingness to envisage an elaborate system of } \\
\text { procedural appeals. }\end{array}$ \\
\hline
\end{tabular}

Agreement to Breukelman v. Heida, arbitrate

[1992] O.J. No. 2604

(QL).

1) $1991 \mathrm{Act}$ applies if arbitration commenced after coming into force.

2) There was no agreement to arbitrate.

Comment: This case is not of general significance.

Confidentiality $\quad 887574$ Ontario Inc. v.

Pizza Pizza Ltd., [1994]

O.J. No. 3112 (Gen.

Div.) (QL) (Same proceeding as below).
Application for direction that court file on appeal from arbitration be sealed. Denied.

Judgment recognizes entitlement to privacy and confidentiality during arbitration and quotes authority. Suggests that even witnesses and experts may be accorded benefit of privacy. But once the dispute goes back into the public sector the usual rules of openness apply.

Comment: The decision recognizes privacy and confidentiality as characteristics of alternative dispute resolution but says that the openness principle prevails once the matter comes into the courts. 


\begin{tabular}{lll} 
Subject & Case & Decision \\
\hline $\begin{array}{l}\text { Standard of } \\
\text { Review }\end{array}$ & $\begin{array}{l}\text { Petrolon Distribution Inc. } \\
\text { v. Petro-Lon Canada Lid., }\end{array}$ & $\begin{array}{l}\text { 1) The agreement (which was entered into under the old } \\
\text { [1995] O.J. No. 1142 }\end{array}$ \\
& $\begin{array}{l}\text { (Gen. Div.) (QL). } \\
\text { issues of law. Court said this meant an appeal as } \\
\text { provided for in the old Act and allowed appeals on } \\
\text { mixed questions. }\end{array}$
\end{tabular}

2) Court said that correctness is the correct standard of review on appeal on law, referring to administrative law authorities.

3) Appeal was on grounds that arbitrator was wrong in refusing to imply in the principal contract a term providing for termination on reasonable notice. Court agreed with the arbitrator and dismissed the appeal.

Comment: The holding that the correctness standard applies on appeal is in accordance with the new Acts. The case is not otherwise significant, though the careful treatment of the arbitrator's reasoning is encouraging.

Enforcement $\quad 887574$ Ontario Inc. v. Pizza Pizza Ltd. (same proceeding as above).
Application to enforce award while appeal and crossappeal on foot. Held discretionary under Ont. s. 50(5) (Alberta s. 49(5)). Granted, subject to providing letters of credit covering refund if franchisor was successful on appeal, because of franchisees' financial condition.

Comment: The court considered the enforcement of the award in much the same way as it might consider the enforcement of a judgment pending appeal. 


\begin{tabular}{|c|c|c|}
\hline Subject & Case & Decision \\
\hline \multirow[t]{4}{*}{ Enforcement } & $\begin{array}{l}\text { Success International Inc. } \\
\text { v. Environmental Export } \\
\text { International of Canada } \\
\text { Inc.,[1995] O.J. No. } 969 \\
\text { (Gen. Div.) (QL). }\end{array}$ & $\begin{array}{l}\text { 1) Application to enforce award dismissed on ground } \\
\text { that applicant was carrying on business in Ontario } \\
\text { without being registered. Application dismissed on this } \\
\text { ground. }\end{array}$ \\
\hline & & $\begin{array}{l}\text { 2) There was no estoppel. The question of registration } \\
\text { was outside arbitrator's jurisdiction and the bringing of } \\
\text { the application was the first occasion when non- } \\
\text { registration could be raised. }\end{array}$ \\
\hline & & $\begin{array}{l}\text { 3) EEI argued that the award was not a final award and } \\
\text { that it was an injunction for which an undertaking to be } \\
\text { responsible for damages was required. The award } \\
\text { directed EEI to speed up its shipping schedules under } \\
\text { the contract. The court rejected these arguments. Under } \\
\text { Ontario s. } 42 \text { (Alberta s. } 41(2) \text { ) a tribunal may make } \\
\text { more than one award, and there was nothing to show } \\
\text { that arbitrator regarded the relief as injunctive. }\end{array}$ \\
\hline & & $\begin{array}{l}\text { Comment: Items } I \text { and } 2 \text { are not of general significance } \\
\text { to arbitration. The third item gives effect to the } \\
\text { provision of the Act about multiple awards. }\end{array}$ \\
\hline
\end{tabular}




\section{ALBERTA DECISIONS}

\begin{tabular}{lll} 
Subject & Case & Decision \\
\hline
\end{tabular}

Stay McCulloch v. Peat Stay of action refused on the grounds that the conspiracy Marwick Thorne-T(1992), and defamation allegations fell outside the arbitration 1 Alta. L.R. (3d) 53 clause and were therefore not capable of arbitration under (Q.B.), 124 A.R. 267. Alberta law.

Rehearing 4 Alta. L.R.

(3d) 185 (Q.B.).

\section{Comment:}

1) References in the first reasons for judgment appear to rely on authorities under the previous broad discretions, but the ratio decidendi appears to be confined to the noninclusion of disputes in the arbitration clause.

2) The decision does not deal with s. 7(5), which permits the court to sever an action and stay those parts relating to disputes that fall under the agreement.

3) If a dispute is not within the agreement, it would seem preferable to hold either that the Act or $s .7(1)$ does not apply rather than say that the dispute is not capable of arbitration.

Pembina Resources Ltd. v. Saskenergy Incorporated et al. (1993), 7 Alta. L.R. (3d) 153, [1993] 3 W.W.R. 549, 135 A.R. 246 (C.A.).
Application for stay of arbitration on grounds notice not given on time and assignee not entitled to arbitrate. Held neither ground valid. Applicant also argued that the court was the more appropriate forum to determine whether a question is arbitrable or whether a call for arbitration is too late or by wrong party and referred to s. 47 . The Court said that the grounds in $\mathbf{s .} 47$ simply barred an arbitration and did not have to do with choice of forum. Court did not purport to say what should be done if there is a factual dispute, e.g., over whether arbitration agreement is forged.

Comment: The statements made in the decision are on the whole supportive, but the decision is not of general significance for arbitration. 


\begin{tabular}{lll} 
Subject & Case & Decision \\
\hline Stay & $\begin{array}{l}\text { Crystal Rose Home Lid. v. } \\
\text { Alberta New Home }\end{array}$ & $\begin{array}{l}\text { 1) Parties can agree to arbitrate a tort claim under the } \\
\text { Arbitration Act. }\end{array}$ \\
$\begin{array}{l}\text { Right to } \\
\text { arbitration }\end{array}$ & $\begin{array}{l}27 \text { Alta. L.R. (3d) } 122 \\
\text { (Q.B. Master) }\end{array}$ & $\begin{array}{l}\text { 2) A dispute over whether a party acted in good faith and } \\
\text { in a commercially reasonable manner as required by PPSA } \\
\text { is included in "any dispute with respect to any matter in } \\
\text { relation to this Agreement." So are the other matters } \\
\text { raised. }\end{array}$
\end{tabular}
raised.

3) Plaintiff claimed that defendant was under a duty to give notice before exercising its remedies and that breach did not come within clause. Held that to escape a stay this would have to be a common law duty, but if there is such a duty it is not an independent tort duty but depends on the contract and is within the clause.

Comment: This judgment gives full effect to the wording the parties have included in the arbitration clause.

Right to arbitration
Bichel v. Alberta (Public Trustee et al. (1993), 7 Alta. L.R. (3d) 262, 136 A.R. 354 (Q.B.).
One ground for granting an application to sever a tort action over an automobile accident from an action by plaintiff against her own insurer under an SEF 44 enforcement was that the court may not have jurisdiction to deal with the SEF action because of an arbitration provision in SEF 44 that said that entitlement and amount shall be determined by arbitration.

Comment: Although the decision appears to be in some doubt as to whether the arbitration provision was effective, it is not of general significance for arbitration. 


\section{Subject Case Decision}

Right to Borowski v. Heinrich 1) Employment relationship is not "commercial" arbitration Fiedler Perforiertechnik relationship, so ICAA did not displace the Arbitration Act. $\mathrm{GmbH}$ (1994), 22 Alta.

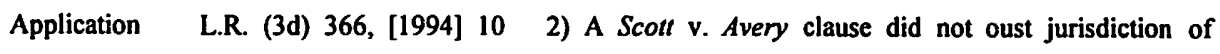
of Act W.W.R. 623,158 A.R. 213 (Q.B.).

3) Arbitration Act applies except as waived or excluded. Direction that arbitration be held in Georgia in accordance with clause. (Question of choice of procedural law not specifically addressed.)

4) Claim that contract had been amended did not take the dispute out of the arbitration clause.

5) Unpaid wages, etc., were not within the clause and action was not stayed for these claims.

Comment: This decision emphasizes that arbitration should proceed where agreed on and that Act applies except where varied or excluded.

Right to arbitration
AltaSteel Lid. v. Inverness Petroleum Lid. (1994), 24 Alta. L.R. (3d) 212, 161 A.R. 138 (Q.B.).
There were two arbitration provisions in the agreement, one mandatory, the other requiring the agreement of both parties. The court held that the issue of price fell under the voluntary arbitration clause.

Comment: The issue on this point was one of interpretation of contracts. The decision is not significant with regard to arbitration generally. 


\begin{tabular}{|c|c|c|}
\hline Subject & Case & Decision \\
\hline \multirow{7}{*}{$\begin{array}{l}\text { Right to } \\
\text { arbitration } \\
\text { Relation to } \\
\text { lien }\end{array}$} & $\begin{array}{l}\text { Bird Construction v. Tri- } \\
\text { City Interiors Ltd. ( } 2 \text { May }\end{array}$ & $\begin{array}{l}\text { 1) As a matter of interpretation, arbitration was mandatory } \\
\text { and the clause was broad enough to cover all of the claims }\end{array}$ \\
\hline & $\begin{array}{l}\text { 1994), Edmonton 9303- } \\
0250-\mathrm{AC} / 9303-0249-\mathrm{AC}\end{array}$ & involved. \\
\hline & (Alta. C.A.). & $\begin{array}{l}\text { 2) Commencing proceedings under the Builders' Lien Act } \\
\text { did not waive the plaintiff's right to arbitration under an } \\
\text { arbitration clause. }\end{array}$ \\
\hline & & 3) The Builders' Lien Act does not prohibit arbitration. \\
\hline & & $\begin{array}{l}\text { 4) While s. } 7 \text { of the Arbitration Act did not permit a } \\
\text { plaintiff to apply to stay its own proceedings, the Court of } \\
\text { Appeal exercised its inherent powers to stay the Builders' }\end{array}$ \\
\hline & & Lien Act proceedings pending arbitration of the merits. \\
\hline & & $\begin{array}{l}\text { Comment: This case is significant. The BLA could be } \\
\text { interpreted as prohibiting arbitration in a builders' lien } \\
\text { case. The Court of Appeal declined to interpret it that } \\
\text { way. Arbitration of the merits of a dispute between the } \\
\text { parties can live with the BLA and proceedings under the } \\
\text { BLA. }\end{array}$ \\
\hline
\end{tabular}

Right to Kvaerner Enviropower

arbitration

Relation to

lien
Inc. v. Tanar Industries

Ltd. (1994), 21 Alta. L.R.

(3d) 182, [1994] 9

W.W.R. 228, 157 A.R.

366 (Q.B.); 24 Alta. L.R.

(3d) 365, [1995] 2

W.W.R. 433 (C.A.).
1) All controversies between Kvaerner and Tanar were controversies which arose out of the commercial legal relationship and in the context of the contract and were capable of being arbitrated. Kvaerner's application for stay granted.

2) Arbitration agreement did not impair Tanar's rights under Builders' Lien Act.

3) Claims of Sovereign (bonding company) as assignee of claims paid under bond could not be determined until arbitration between Kvaerner and Tanar, so Sovereign's action is stayed, with Sovereign (though not a party to arbitration agreement) to be given notice and entitled to participate in arbitration.

Comment: This is an ICAA case but is included because of its significance for Arbitration Act cases. It points out that s. 3 of the BLA could be interpreted as prohibiting arbitration but declares the policy of the law to be to permit arbitration. 
Subject Case Decision

Right of Pachanga Energy v. Mobil 1) Method of assessment used by arbitrator to value appeal Investments Canada Inc. equipment in fixing amount of award was a mixed et al. (1993), 8 Alta. L.R. question of fact and law and there was therefore no right (3d) 284, [1993] 4 to appeal under Arbitration Act s. 44(2). Appeal W.W.R. 176, 138 A.R. dismissed.

309 (Q.B.), (1994) 15

Alta. L.R. (3d) 1, [1994] 3 2) Held by QB, not dealt with by CA, that if there was a W.W.R. 350, 149 A.R. 73 question of law it was expressly referred so that s. 44(3) (C.A.). precluded appeal. The question referred was one of valuation.

Comment: The decision construes the right of appeal under s. 44(2) correctly. The $Q B$ decision that the question was "expressly referred" extends s. 44(3), as the question was not mentioned in the reference. 


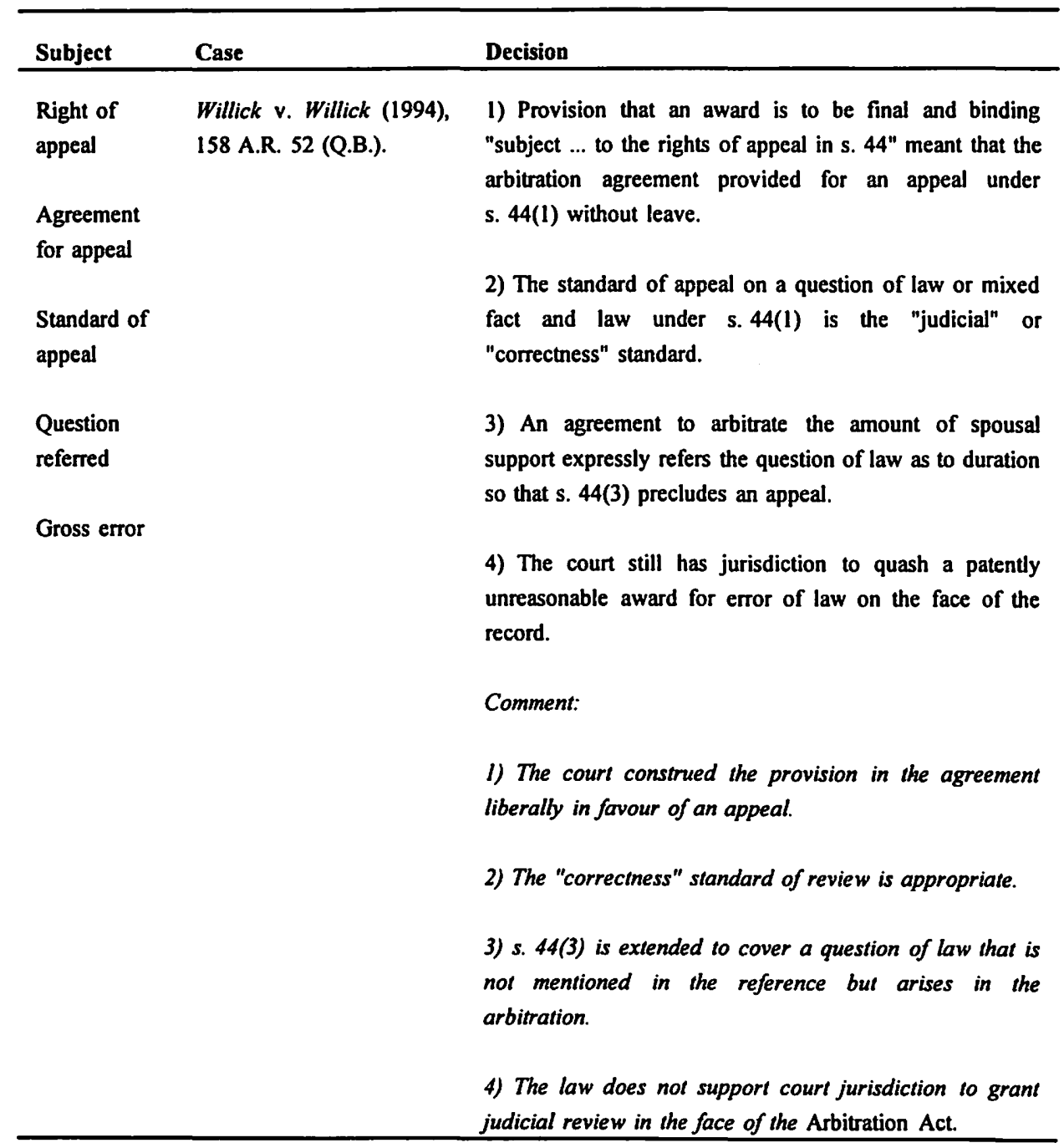




Subject Case Decision

Right of Aztec Construction Ltd. v. 1) Agreement referred the question whether Frocan made appeal Frocan Industrial a unilateral mistake that would void the contract. Contractors Ltd. (1994), Arbitrator said yes. Held that the question was "expressly 24 Alta. L.R. (3d) 440, referred" and s. 44(3) precluded appeal.

161 A.R. 314 (Q.B.).

2) Parties explicitly agreed to grant to the arbitrator "complete discretion with respect to the award of costs ...." Held that arbitrator's award of solicitor and client costs could not be appealed, apparently because of s. $44(3)$.

Comment: The decision appears to extend s. 44(3) to cases in which a question referred is partly a question of law and partly a question of fact, thus removing such cases from the ambil of an appeal under s. 44(2) on a question of law.

Right of

Appeal
Canadian Western Natural

Gas Co. v. Alberta Energy

Co., [1995] A.J. 310 (QB)

(Q.L.).
Application for leave to appeal. Refused.

1) Interpretation of s. 12 of the Natural Gas Marketing $A C t$ is one of law alone, but the tribunal has unfettered discretion so long as it considers the factors listed in $\mathbf{s .} 12$.

2) Determination of gas price is a question of mixed fact and law, so that appeal does not come within s. 44(2), question of law.

Comment: The decision restricts the right of appeal in s. 44(2) to a question of law alone and therefore does not favour the right. $t$ is not of general significance for arbitration.

Appeal Aztec Construction 1) Filing of an application for leave to appeal within 30 practice Limited v. Frocan Industrial Contractors and Wheeler (1993), 14 Alta. days is sufficient under $\mathbf{s .} 46$ without service in that time.

L.R. (3d) 26, 144 A.R. 276 (Q.B.).

2) Where there has been a correction, explanation or change of reasons, the whole award may be appealed within thirty days of receiving same.

Comment: This decision appears to be a reasonable interpretation of the requirements of the Arbitration Act with respect to the time for appeal. 


\begin{tabular}{|c|c|c|}
\hline Subject & Case & Decision \\
\hline \multirow[t]{3}{*}{ Enforcement } & $\begin{array}{l}\text { Bruneau v. Bruneau (18 } \\
\text { March 1993), A.C.L. No. } \\
930221 \text { (Alta. Q.B.). }\end{array}$ & $\begin{array}{l}\text { 1) Wife had appealed consent order to arbitrate, } \\
\text { appointment of arbitrator and refusal to stay arbitration } \\
\text { proceedings. Her application for stay of enforcement } \\
\text { pending appeal was allowed on grounds that she would } \\
\text { suffer irreparable harm from sale of the matrimonial home } \\
\text { and balance of convenience favoured stay. }\end{array}$ \\
\hline & & $\begin{array}{l}\text { 2) s. } 48 \text { is ambiguous as to whether appeal of award can } \\
\text { be brought before Court of Appeal with leave rather than } \\
\text { Court of Queen's Bench. }\end{array}$ \\
\hline & & $\begin{array}{l}\text { Comment: Although a court would probably hold that } \\
\text { s. } 48 \text { applies only to appeals from the Court of Queen's } \\
\text { Bench, it should be clarified. The case is not of general } \\
\text { significance for arbitration. }\end{array}$ \\
\hline
\end{tabular}




\section{SASKATCHEWAN DECISIONS}

\begin{tabular}{llll}
\hline Subject & Case & Decision & Rating \\
\hline Stay & $\begin{array}{l}\text { Pulvermacher v. } \\
\text { Pulvermacher. [1994] } \\
\text { S.J. No. 595 (QL). }\end{array}$ & $\begin{array}{l}\text { Plaintiff obliged to sell his shares to other Confirms } \\
\text { shareholders because his employment with agreement } \\
\text { company was terminated. Sued, alleging to } \\
\text { conspiracy to obtain shares at less than market arbitrate. } \\
\text { value and consequent unjust enrichment }\end{array}$ \\
& $\begin{array}{l}\text { Held that whether plaintiff is entitled to fair } \\
\text { market value or some other market value is a } \\
\text { dispute between the parties which they have } \\
\text { agreed to have resolved by arbitration. }\end{array}$ \\
& $\begin{array}{l}\text { Distinguishes McCulloch v. Peat Marwick on } \\
\text { the grounds no tortious conspiracy is alleged. } \\
\text { No reference to Deluce, but no oppression } \\
\text { claim. }\end{array}$ \\
& $\begin{array}{l}\text { Comment: The case shows a disposition to hold } \\
\text { parties to arbitration. }\end{array}$
\end{tabular}

